\title{
Arabia in the Light of the Midnight Sun: Arabic Studies in Sweden between Gustaf Peringer Lillieblad and Jonas Hallenberg*
}

\author{
Bernd Roling \\ Introduction
}

When August Strindberg was learning Hebrew, countless words passed in front of him that seemed totally Swedish to him, as he describes in his own words in his Blue Book. Had he not been taught that there was a 'chasm' between the Germanic and Semitic languages? The very first words in the dictionary suggested the opposite. Aborren was Swedish for the freshwater perch, but it had no etymological explanation. Neither the German word Barsch nor its Latin equivalent perca seemed much help. Yet the Icelandic word for perch, abor, sounded like the German Eber, that is, 'boar', and even more like the Hebrew word for 'strong', namely abir. And was not the aborre, the wild boar among freshwater fishes? Did it not bristle with strength? In Old Swedish the creature was called aghbar. Did that not sound like the Arabic superlative akbar? Would he not gain a better understanding of the many puzzling words in Swedish by seeking the Semitic roots of his native language? ${ }^{1}$ Already in the Blue Book, a summa of the author's views of the world and all the sciences, these reflections had led Strindberg to study Chinese, Manchurian and various Finno-Ugric languages for their links to Hebrew, thus rejecting the dominant approach to the ancient Semitic languages in the early twentieth century, which was primarily

* This study is a result of the project 'The Linneans and the Bible', led by Outi Merisalo (Jyväskylän yliopisto) and myself, Bernd Roling (Freie Universität Berlin), as a part of the HERA research project 'Encounters with the Orient'. I would like to thank the University Libraries of Greifswald, Göttingen, Uppsala, and Lund, the Kansallis Kirjasto of Helsinki, and my collegues, assistants and students Outi Merisalo, Benjamin Hübbe, Bernhard Schirg, Stefan Bauhaus, Ramune Markeviciute, Helena Winterhager (Freie Universität Berlin), especially, Orla Mulholland (Berlin), Dorothee Huff(Göttingen), and Peter Sjökvist and Anna Fredriksson (Uppsala) for their kind support.

1 In German see A. Strindberg, Ein Drittes Blaubuch, transl. E. Schering, Munich, 1921, there 'Die Ahnen der Muttersprache', pp. 1255-6. The piece was not included in the original printed Swedish version of the blå bok, but taken by the translator Schering from the heritage. 
the study of cuneiform literature. ${ }^{2}$ Several special studies of Chinese, of The Roots of World Languages, Biblical Proper Names and The Origins of Our Mother Tongue followed in 1910 and $1911 .^{3}$

Strindberg's untrammelled delight in associations gave more weight to sound sequences than to grammatical structures and oscillated between brilliance and dilettantism, but it was more than just a philological expression of the doctrine of all-encompassing correspondences to which Strindberg was committed as a follower of Swedenborg. It was also heir to an approach and methods that had made Oriental studies into a baroque patriotic pursuit, and which perhaps had a greater influence in Sweden than in other learned settings in Europe. The dignity of one's mother tongue would surely be enhanced if it could be matched to the pattern of the First Language. A Swedish national ideology arose after the Thirty Years' War that provided this new European empire, from Lapland to Pomerania, with a prehistory tailored to the idea of the North as a universal civilising power. It was in the same era that the first chairs in Oriental languages were established at the universities of the Swedish empire, in Uppsala, Lund, Turku, Tartu, Pernau and Greifswald. ${ }^{4}$ This paper

2 A. Strindberg, En blå bok, Samlade Verk 65, ed. G. Ollén, Stockholm, 1997, e.g. 'Hammurabis inspirerade Lagar', pp. 419-20; id., En ny blå bok, Samlade Verk 66, ed. G. Ollén, Stockholm, 1999, 'Om Urspråket och Babels Förbistring', pp. 779-83, 'Urspråket och Urreligionen', pp. 801-4, 'Svenska och Hebraiska', pp. 805-6, 'Hebraiska Studier', pp. 8o9-11', 'Kinesiska Språket', pp. 812-14, 'Finska, Ungerska, Mandchuiska, Japanska', pp. 837-45, id., En blå bok. Avdeling III. En extra blå bok, Samlade Verk 67, ed. G. Ollén, Stockholm, 2000, 'Jahveh-Namnet', pp. 1479-85, 'Kilskrift-liknande tecken', p. 1486, 'Kinesiska Språkets Hemlighet', p. 1522, and see also H. Jonsson, 'Hebreiskan, urspråket och diverse språjamförelser', in En ny blå bok, pp. 1093-8. In German see A. Strindberg, Ein Blaubuch. Die Synthese meines Lebens, 2 vols, transl. E. Schering, Munich. 1920, vol. 1, 'Hammurabis inspirierte Gesetze', pp. 435-6, and vol. 2, 'Von der Ursprache und Babels Verwirrung', pp. 674-9, 'Ursprache und Urreligion', pp. 598602, 'Schwedisch und Hebräisch', pp. 603-5, 'Hebräische Studien', pp. 608-10, 'Die chinesische Sprache', pp. 611-13, 'Finnisch-Ungarisch-Mandschurisch-Japanisch', pp. 639-46; and also A. Strindberg, Ein Drittes Blaubuch, 'Der Jahweh-Name', pp. 1202-10, 'Keilschriftähnliche Zeichen', p. 1211, 'Das Geheimnis der Chinesischen Sprache', pp. 1253-5.

3 A. Strindberg, Bibliska egennamn med ordfränder i klassiska och lefvande språk, Stockholm, 1910; A. Strindberg, Modersmålets anor: Svenska ordfränder i klassiska och lefvande språk, Stockholm, 1910; A. Strindberg, Världs-Språken Rötter, Stockholm, 1911.

4 On the general history of the universities in 17th and 18th century Sweden see the surveys of C. Annerstedt, Uppsala Universitets Historia. Andra Delen. 1655-1718, 2 vols, Uppsala, 1908-09; C, Annerstedt, Uppsala Universitets Historia. Tredje Delen. 1719-1792, 2 vols, Uppsala, 1913-14; J. Rosén, Lunds Universitets historia 1:1668-1709, Lund, 1968; G. Johannesson, Lunds Universitets historia 2: 1710-1789, Lund, 1982; K. Gierow, Lunds Universitets historia 3: 1790-1867, Lund, 1971; K.G.T. Rein, Filosofins studium vid Åbo universitet, Helsinki, 1908; H. Råberg, Teologins historia 
will present in synopsis how, in the seventeenth century, the study of Arabic was developed by drawing on Sweden's own models of national supremacy and how, both inspired by these and defined against them, it became established as an independent discipline. Editorial scholarship and biblical antiquarianism and philology all took root in the Baltic region as elsewhere, but here they were loaded with a baroque universalism which was itself perhaps a condition of their genesis. The conditions in which Swedish Arabic studies arose will be reconstructed here through two figures in particular, Gustaf Peringer Lillieblad (1651-1710) and Jonas Hallenberg (1748-1834), whose combined lifespans cover the whole of the eighteenth century. While Peringer's name is associated with the process of establishing the discipline, the figure of Hallenberg, as will be shown, reveals how long Oriental studies in Scandinavia remained true to the outlook of baroque universalism.

\section{The Historia linguae et eruditionis Arabum of Gustaf Peringer and Olaus Celsius}

Arabic studies in Sweden began with a foundational act, undertaken in the late seventeenth century by the two most important Orientalists of the Swedish empire, Gustaf Peringer Lillieblad, already established as a professor, and his respondent, the young Olaus Celsius $(1670-1756)$, from the family of the Celsii. ${ }^{5}$ In 1694 they published their Historia linguae et eruditionis Arabum, presented as a disputation, which marks the start of the history of Swedish Arabic stud-

vid Åbo universitet, 2 vols, Helsinki, 1893-1901; I.A. Heikel, Filologins studium vid Åbo universitet, Helsinki, 1894; G. von Rauch, Die UniversitätDorpatund das Eindringen derFrühaufklärung in Livland 1690-1710, Essen, 1943; H. Piirimäe, Ülikoolilinn Pärnu, Tartu, 1999; M. Klinge, Eine nordische Universität. Die Universität Helsinki 1640-199o, Helsinki, 1992, pp. 13-197; and S. Lindroth, A History of Uppsala University 1477-1977, Uppsala, 1976, pp. 15-146.

On Gustaf Peringer Lillieblad's life and works in general see first of all the collected studies in the volume of É.Á. Csató, G. Gren-Eklund and F. Sandgren, En resenär I svenska stormaktstidens språklandskap. GustafPeringer Lillieblad (1651-1710), Uppsala, 2007; and earlier the classical study by H. Schoeps, Philosemitismus im Barock, Tübingen, 1952, pp. 134-5, pp. 145-7, pp. 151-3, pp. 184-7; and K.V. Zetterstéen, 'Gustaf Peringer Lilieblands Hebreiska Oration vid Jubelfesten i Uppsala 1693', in Teologiska Studier tillägnade Erik Stave på 65-årsdagen, Uppsala, 1922, pp. 11-28, here pp. 11-15. On Olaus Celsius see first of all Annerstedt, Uppsala Universitets Historia. Tredje Delen. 1719-1792, vol. 2, pp. 339-45; and S. Lindroth, Svensk Lärdomshistoria, 4 vols, Stockholm, 1975, vol. 2, pp. 226-7, vol. 3, p. 647. Other studies will be mentioned below. 
ies. ${ }^{6}$ In this work, neither scholar is in any doubt that he must build new foundations. Almost all of their Historia can thus be read as a manifesto for a branch of scholarship that was yet to be established at the Swedish universities, and as a defence of Arabic studies as a whole. At the same time, Peringer and Celsius provide a catalogue of primary and secondary literature which, as we shall see, would subsequently achieve near-canonical status in Sweden.

\section{The Beginning of Arabic Studies in Sweden}

The two scholars first strive to legitimize their object of study. What is the origin of the Arabic language?7 Jewish tradition had linked Arabic to the descendants of Ishmael, as Peringer recalls, and Thomas Erpenius had suggested that Ham was the progenitor of the Arabs, ${ }^{8}$ but authoritative sources like Samuel Bochart, ${ }^{9}$ the father of Oriental geography, ${ }_{10}^{10}$ and Edward Pococke had already demonstrated that Joktan from Mesha in Sephar, mentioned in Genesis, must be the true progenitor of the Arabs. ${ }^{11}$ Only later had the Israelites become part of the Arab community. Joktan had spoken perfect Hebrew, like later members of the Arab people such as Jethro, with whom Moses was able to converse. ${ }^{12}$ Arabic must therefore be considered to derive directly from Hebrew and is thus of a similar dignity and purity, a point that had already been demonstrated for Swedish by the great Gothicist Georg Stiernhielm, ${ }^{13}$ as

6 G. Peringer Lillieblad - O. Celsius (resp.), Historia linguae et eruditionis Arabum, Uppsala, 1694. Parts of the Historia were reprinted in the Bibliotheca Bremensis nova historico-philologico-theologica, Bremen, 1764, see there vol. 4, fasciculus 1, pp.1-54; fasciculus 2, pp. 203-88, and fasciculus 3, pp. 373-435. Peringer - Celsius, Historia linguae et eruditionis Arabum, ch. 1, pp. 1-8.

8 T. Erpenius, Oratio de linguae arabicae praestantia et dignitate, Leiden, 1613 , fol. $\mathrm{A}_{4}^{\mathrm{r}}-\mathrm{A}_{4}^{\mathrm{v}}$. On Erpenius's role in Oriental studies see still J. Fück, Die Arabischen Studien in Europa bis in den Anfang des 20. Jahrhunderts, Leipzig, 1955, pp. 59-73. On Bochart's achievements in Oriental geography see Z. Shalev, Sacred Words and Worlds. Geography, Religion, and Scholarship, 1550-170o, Leiden, 2012, pp. 141-204. S. Bochart, Geographia sacra, cuius pars prior Phaleg De dispersione gentium et terrarum divisione facta in aedificatione turris Babel, pars posterior Chanaan De coloniis et sermone Phoenicum agit, Frankfurt, 1681, Liber II, ch. 15, pp. 109-12. E. Pococke, Specimen Historiae Arabum sive Gregorii Abul Farajii Malatiensis De Origine et Moribus Arabum, Oxford, 1650, Notae, pp. 38-41.

12 Peringer-Celsius, Historia linguae et eruditionis Arabum, ch. 1, pp. 8-9.

13 G. Stiernhielm, Jesu Christi Evangelia ab Ulfila Gothorum in Moesia Episcopo circa annum a nato Christo CCCLX ex Graeco Gothice translata, nunc cum parallelis versionibus SveoGothica, Norraena seu Islandica et vulgata Latina edita, Stockholm, 1671, see there the extensive praefatio fols a $3^{\mathrm{r}}-\mathrm{F}_{3} \mathrm{r}$. 
Peringer notes. ${ }^{14}$ The Arabic script, too, he continues, had arisen from the original Hebrew alphabet and was of majestic antiquity. Other types of script, above all Kufic, but also Syriac or Persian, were secondary relative to Arabic. ${ }^{15}$ In their discussions Peringer and Celsius draw on the relevant authorities in their field, especialy Henning Henningsen's Muhammedanus precans, ${ }^{16}$ Johann Heinrich Hottinger's Historia ecclesiastica, together with many other of Hottinger's treatises, ${ }^{17}$ and Edward Pococke's Specimen, but also works less well known today, ${ }^{18}$ such as Georg Welsch's Ruzname, which had appeared a few years previously. ${ }^{19}$ The immense continuity of the Arabic language could be demonstrated through the Arabic proper names found in Greco-Roman literature long before the earliest extant Arabic writings. Had not Hirtius in his Bellum Alexandrinum spoken of a king called 'Malak'?20 Had not Cassius Dio, too, in his Roman History mentioned a princeps with the no less informative name 'Sabus'? ${ }^{21}$ Already the northern German scholar Henning Henningsen, ${ }^{22}$ like Johann Heinrich Hottinger, ${ }^{23}$ Edward Pococke ${ }^{24}$ and the Danzig scholar Johannes Fabricius in his Specimen arabicum, a work that was of great importance to Peringer, had noted the almost clinical purity of Arabic and its direct, almost mirror-like derivation from Hebrew. The Arabs had never been subjected by conquest to foreign rule; no foreign loanwords had entered their

14 Peringer - Celsius, Historia linguae et eruditionis Arabum, ch. 1, pp. 4-5.

15 Ibid., ch. 1, pp. 10-14.

16 H. Henningsen, Muhammedanus precans, id est Liber precationum Muhammedicarum arabicus manuscriptus, Schleswig, 1666.

17 On Johannes Heinrich Hottinger's extensive writings and his role in the learning of Arabic see the excellent study by J. Loop, Johann Heinrich Hottinger. Arabic and Islamic Studies in the Seventeenth Century, Oxford, 2013, passim.

On Edward Pococke's role in the history of Islamic studies see e.g. B.P.M. Holt, 'The Study of Arabic Historians in Seventeenth Century England: The Background and the Work of Edward Pococke', in Bulletin of the School of Oriental and African Studies, 19, 1957, pp. 444-55; and G.J. Toomer, Eastern Wisedome and Learning in Seventeenth-Century England, Oxford, 1996, pp. 116-47, pp. 155-66, pp. 271-9, p. 294.

G.H. Welsch, Commentarius in Ruzname naurus sive Tabulae aequinoctiales novi Persarum et Turcarum anni, Augsburg, 1676.

20 Gaius Julius Caesar, Commentarii, ed. A. Klotz, Stuttgart, 1966, Bellum Alexandrinum, ch. 1, p. 1 .

Cassius Dio, Roman History, ed. E. Cay, 9 vols, Cambridge, MA., 1968, vol. 6, Book 53, § 29, Greek and English, pp. 268-9.

22 Henningsen, Muhammedanus precans, pp. 284-7.

23 J.H. Hottinger, Etymologicum orientale sive Lexicon harmonicum heptaglotton, Frankfurt, 1661, Praefatio, fols a $3{ }^{\mathrm{v}}-\mathrm{b} 3^{\mathrm{r}}$.

24 Pococke, Specimen Historiae Arabum, pp. 150-1. 
speech. ${ }^{25}$ It was above all this closeness to origins, Peringer and Celsius stress, that gave Arabic its special appeal. ${ }^{26}$

There was an apparent contradiction to the dignity of ancient Arabic in the fact that the Arabs themselves had given a rather low estimate of the status of their culture before the coming of the Prophet and had characterized that period, as had been shown by Johannes Fabricius and Edward Pococke, as the 'Age of Ignorance.' ${ }^{27}$ But was this verdict of Arabic historiography just? ${ }^{28}$ For Peringer, the early Arabs must, rather, have had special knowledge due to their closeness in time and culture to the Biblical revelation. This knowledge consisted of astronomical knowledge and a philosophy of the celestial bodies that which was still closely connected to the scriptural revelation. ${ }^{29}$ Scripture itself offered witnesses to the special erudition of the ancient Arabs, in the Arabicspeaker Job, who had praised the Creator's power over the celestial bodies, and his interlocutors, Bildad the Shuhite, Eliphaz the Temanite and Zophar the Naamathite, who were clearly exponents of philosophical eloquence similar to that of Job, and in Jethro, who had already been identified as an Arab by Hottinger. ${ }^{30}$ Even more emphatic proof of the wisdom of the ancient Arabs was provided by the figure of Luqman. ${ }^{31}$ As Peringer notes, this person too had already been given due weight by Abul-Faragius, as translated into Latin by Pococke. ${ }^{32}$ One whole sura of the Qur'an had praised this man as a contemporary of King David, and Christian Ravius had wanted to see him as the poet Alcman. ${ }^{33}$ Johann Heinrich Hottinger had presented numerous plausible arguments for identifying Luqman as none other than Aesop, whose fables were

25 J. Fabricius, Specimen arabicum quo exhibentur aliquot scripta arabica, partim in Prosa, partim Ligata oratione composita, Rostock, 1638, p. 7. On Fabricius' Specimen and its background and impact see the Jan Loop's essay in this volume.

26 Peringer - Celsius, Historia linguae et eruditionis Arabum, ch. 2, pp. 24-30.

27 Pococke, Specimen Historiae Arabum, Notae, p. 52; Fabricius, Specimen arabicum, p. 25.

28 Peringer - Celsius, Historia linguae et eruditionis Arabum, ch. 2, pp. 31-3.

29 Ibid., ch. 2, pp. 34-42.

30 J.H. Hottinger, Smegma orientale sordibus barbarismi, Heidelberg, 1658, Liber I, ch. 8, p. 412; and ibid., Thesaurus philologicus seu Clavis Scripturae, Zürich 1659, Liber II, ch. 1, Sectio 3, pp. 499-500.

$3^{1} \quad$ Peringer - Celsius, Historia linguae et eruditionis Arabum, ch. 2, pp. 42-4.

32 G. Abul-Faragius, Historia compendiosa Dynastiarum, Oxford, 1663, in Latin p. 33, in Arabic p. 51; and similiarly Fabricius, Specimen arabicum, pp. 207-8; and e.g. W. Schickard, Tarich, hoc est Series Regum Persiae ab Ardshir-Babekan, usque ad Iazdigerdem a Chaliphis expulsum, Tübingen, 1628, pp. 19-20.

33 C. Ravius, Prima tredecim partium AlCorani arabico-latini, Amsterdam, 1646, fol. C C $^{\mathrm{r}}$. 
echoed in the Qur'an. ${ }^{34}$ Further, Peringer and Celsius continue, the Books of Kings link the wisdom of Solomon to the wisdom of the Arabs and praise the Queen of Sheba, called Belkis in the Arabic tradition, as its outstanding proponent. ${ }^{35}$ Was there not here, as Bochart and Jacob Golius had already stressed, a whole arsenal of pre-Islamic learning? ${ }^{36}$ Why would it have been said that Democritus or Pythagoras had travelled to Arabia, if that were not the point of origin of knowledge of the stars? ${ }^{37}$

A temporary end to the postulated Arabian civilisation occurred, according to Peringer and Celsius, with the coming of the Prophet, about whom the two Uppsala scholars, as is to be expected, had little good to say. ${ }^{38}$ Peringer admits that some authors had noted, with regard to the Qur'an, that Muhammad's lack of education was strong evidence of its miraculous character. ${ }^{39}$ In reality, however, he says, it was the monk Sergius, a figure cited by anti-Qur'anic polemicists for centuries, who was responsible for the composition of the text, rather than a divine revelation ${ }^{40}$. Peringer knew that both Lodovico Marracci and Abraham Hinckelmann had worked on complete editions of the Qur'an;11 he was also familiar with the numerous editions of individual suras presented

34 J.H. Hottinger, Historia orientalis, ex variis orientalium monumentis collecta, Zürich, 1651, Liber I, ch. 3, pp. 70-2; and see T. Erpenius, Locmanni sapientia fabulae et selecta quaedam Arabum Adagia, Leiden, 1636.

Peringer - Celsius, Historia linguae et eruditionis Arabum, ch. 2, pp. 46-8.

36 Bochart, Geographia sacra, Liber II, ch. 26, pp. 151-4; Pococke, Specimen Historiae Arabum, Notae, pp. 85-6; and Alfraganus, Elementa astronomica, opera J. Golii, Amsterdam, 1669, Notae, pp. 86-8.

39 Pococke, Specimen Historiae Arabum, Notae, pp. 165-8; and Hottinger, Historia orientalis, Liber I, ch. 5, pp. 143-4. Peringer - Celsius, Historia linguae et eruditionis Arabum, ch. 3, pp. 56-7.

41 L. Marracci, Alcorani textus universus ex correctioribus Arabum exemplaribus summa fide, atque pulcherrimis characteribus descriptus ac in Latinum translatus, apositisque unicuique capiti notis, atque refutatione: His omnibus praemissus est Podromus totum priorem tomum implens, 2 vols, Padova, 1698; and A. Hinckelmann, AlCoranus s. Lex Islamitica Mohammedis, Filii Abdallae Pseudoprophetae, Hamburg, 1694. On the famous Qur'antranslation by Marracci see e.g. G. Levi della Vida, 'Ludovico Marracci e la sua opera degli studi islamici', in id., Aneddoti e svaghi arabi e non arabi, Milano, 1959, pp. 193-210; and M. Borrmans, 'Ludovico Marracci et sa traduction latine du Coran', in Islamochristiana, 28, 2002, pp. 73-86; and see recently esp. R. Glei, 'Scripture and Tradition. Traces of Counter-Reformatory Discourse in Marraci's Work on Islam', in Esperienza e rappresentazione dell'Islam nell'Europa mediterranea (secoli XVI-XVIII), eds A. Celli and D. Scotto, Florence 2015, pp. 671-689, and id. and R. Tottoli, Ludovico Marracci at work: the evolution of his Latin translation of the Qur'ān in the light of his newly discovered manuscripts, with an edition and a comparative linguistic analysis of Sura 18, Wiesbaden, 2016, passim. 
by Petrus Kirstenius ${ }^{42}$ Thomas Erpenius ${ }^{43}$ or Johann Georg Nissel. ${ }^{44}$ Queen Christina alone owned thirteen manuscripts of the Qur'an which were still awaiting study. The Umayyad caliphate had only deepened the cultural breach introduced by Islam. ${ }^{45}$ Pococke's Abul-Faragius and Jirjis b. al-'Amīd al-Makīn, Georgius Elmacinus, in his Historia saracenia, which Erpenius had published in Latin, had made this clear enough through their account of the burning of the Alexandrian library and of the first caliphs' opposition to learning. ${ }^{46}$ All that this era had produced was coins, as was known from Hottinger; ${ }^{47}$ some of these had been discovered in excavations even in Sweden, as recently in Örebrö. 48

The situation in the Arab world had changed only under the Abbasids, Peringer and Celsius concluded, at which point the Arabs became the most important guardians of the classical tradition ${ }^{49} \mathrm{Ha} r u \bar{n}$ al-Rashīd and al-Manșūr had undertaken a major project of translation, parts of which - numerous works by Aristotle, Euclid and Plotinus - Peringer could find in Hottinger's Bibliotheca orientalis, as well as in Pococke and John Greaves's prefaces to their editions of Abū l-Fidā' and al-Ḥusayn b. 'Alī al-Ṭughrāīi. ${ }^{50}$ How many works from the ancient world would never have reached the Renaissance if the Arabs had not preserved them across the centuries? A catalogue of Arab scholars then follows on almost forty pages, arranged by discipline and citing not only Al-Kindī, Abū Ma'shar, Avicenna, Averroes and Al-Battānī, but also Ibn al-

42 P. Kirstenius, Tria specimina characterum arabicorum, Breslau, 16o8, pp. 7-10.

43 T. Erpenius, Historia Josephi Patriarchae ex Alcorano arabice, Leiden, 1617 , fols $\mathrm{D}_{2}^{\mathrm{r}}-\mathrm{H}_{4}{ }^{\mathrm{v}}$.

44 J.G. Nissel, Testamentum inter Muhamedem legatum Dei et christianae religionis populos olim initum, ut et Suratarum Alcorani decimaquartae et decimaquintae, Leiden, 1655, with separated pagination.

45 Peringer - Celsius, Historia linguae et eruditionis Arabum, ch. 3, pp. 62-4.

46 G. Abul-Faragius, Historia compendiosa Dynastiarum, in Latin pp. 114-15, in Arabic pp. 181-2; G. Elmacinus, Historia saracenica, qua res gestae Muslimorum explicantur, Leiden, 1625, Liber I, ch. 3, pp. 29-30.

47 J.H. Hottinger, Dissertatio de nummis orientalium, Hebraeorum maxime et Arabum., in ibid., Cippi Hebraici, Heidelberg, 1662, pp. 89-188; and see as Peringer's authority also A. Morell, Specimen universae rei numariae antiquae, Paris, 1683, pp. 132-33.

48 Peringer - Celsius, Historia linguae et eruditionis Arabum, ch. 3, p. 65.

49 Ibid., ch. 3, pp. 66-9.

50 J. Greaves, Chorasmiae et Mawaralnahrae, hoc est regionum extra fluvium Oxum descriptio ex tabulis Abulfedae Ismaelis, London, 165o, praefatio, fols aa ${ }^{\mathrm{r}}-\mathrm{aa} 3^{\mathrm{v}}$; E. Pococke, Lamiato'l Ajam, Carmen Tograi poetae Arabis doctissimi, Oxford, 1661, praefatio, fols $4^{\mathrm{r}}-8^{\mathrm{r}}$; and for Peringer's list of texts J.H. Hottinger, Promtuarium sive bibliotheca orientalis, Heidelberg, 1658, Liber III, Pars II, ch. 2, pp. 215-41. 
Haytham and al-Bīrūnī. ${ }^{11}$ Peringer stresses that it was not just in astronomy, mathematics and medicine that Arabic science was far ahead of the Latin world. Arabic historiography, too, as Johann Heinrich Hottinger and Matthias Wasmuth had shown, was superior to Western history writing in its precision and impartiality; ${ }^{52}$ Christian Ravius had even found a history of Alexander the Great. ${ }^{53}$ And the quality of the language was worthy of the subject it presented, as Peringer illustrates on a further twenty pages. ${ }^{54}$ In this assessment, too, the Swedish scholars were able to draw on the great English authorities for their debate and on recently prepared editions. As a scholarly language Classical Arabic had the advantage of a stupendous vocum emphasis and proprietas and a rotunda copia et brevitas, and in this, as was demonstrated not least by Avicenna's Canon, it had no peer among all languages. ${ }^{55}$ It was distinguished by a foecunditas vocum, which, as Pococke had shown, could form eighty synonymous terms just for 'ruler', ${ }^{6}$ and which in historiography also permitted an especially subtle form of ambiguity and a singular acumen. The later variants of Arabic, whose land of origin had been conquered by the Turks and Tartars, could no longer rival this apogee of Arabic language and culture, as Peringer stressed. ${ }^{57}$

The final part of the Historia linguae et eruditonis Arabum consists of a separate history of Arabic studies in Europe, beginning among the Arabic Jews, with Saadia Gaon and Maimonides and including the Oriental and European Karaites. Peringer and Celsius summerize medieval interest in Arabic and the first Latin translations from the hands of figures like Petrus of Tivoli or Adelard of Bath, whose provisional character and later influence Peringer is able to demonstrate with a list of wrongly transcribed medical terms. ${ }^{58}$ There follows a synopsis, country by country, of early modern Arabic studies, which details at

$5^{1} \quad$ Peringer - Celsius, Historia linguae et eruditionis Arabum, ch. 3, pp. 70-105.

$5^{2}$ M. Wasmuth, Grammatica arabica, Amsterdam, 1644, Paraenesis de linguae arabicae utilitate, fols $\mathrm{II}^{\mathrm{r}}-\mathrm{II} 2^{\mathrm{v}}$; and a basic list of texts in Hottinger, Promtuarium sive bibliotheca orientalis, Liber III, Pars II, ch. 2, pp. 271-5.

C. Raue, Spolium orientis christiano orbi dicatum, Kiel, 1669 , Centuria II, no. 38.

54 Peringer - Celsius, Historia linguae et eruditionis Arabum, ch. 3, pp. 105-14.

55 P. Kirstenius, Liber secundus de Canone canonis a filio Sina, Breslau, 16og, Praefatio, pp. 1-5; L. Warner, Proverbiorum et sententiarum persicarum centuria, Leiden, 1644, Praefatio, fols $4^{\mathrm{r}}-5^{\mathrm{v}}$.

56 Pococke, Specimen Historiae Arabum, Notae, p. 153.

57 Peringer-Celsius, Historia linguae et eruditionis Arabum, ch. 4, pp. 120-37. See as Peringer's authority T. Hyde, Tabulae longitudinis ac latitudinis stellarum fixarum ex observatione Ulugh Beighi Tamerlanis Magni Nepotis, Oxford, 1665, praefatio (without pagination).

$5^{8} \quad$ Peringer-Celsius, Historia linguae et eruditionis Arabum, ch. 5, pp. 139-58. 
length the achievements of Hottinger, Ludolf, Wasmuth, Filippo Guadagnoli, John Selden and William Bedwell. ${ }^{59}$ But what was the position of Arabic studies in Peringer's homeland, in Sweden? Textbooks in Hebrew studies had been produced and theologians like Johannes Buskragius and Johannes Terser had emphasized the importance of Oriental studies, as had Erpenius before him. ${ }^{60}$ But that was all. And why was knowledge of Arabic so useful? Arabic was needed, of course, to spread the truth of the Gospel in Arabia too. Both Peringer and Celsius had highlighted the antiquity of Arabic and its direct derivation from the lingua adamica. Arabic must therefore have a key role as an exegetical resource. ${ }^{61} \mathrm{~A}$ number of obscure passages of Scripture could be explained with the help of Arabic. This special importance of the language according to Peringer had been demonstrated with copious examples by Johann Heinrich Hottinger, ${ }^{62}$ as well as by Louis de Dieu in his commentaries on the New Testament. ${ }^{63}$ Furthermore, as had already been made clear by earlier apologists for Arabic studies, Thomas Erpenius and Christian Ravius, the Arabs' enormous achievements in science meant that knowledge of Arabic must be of great utility also for physicians, mathematicians and politicians, indeed for everyone interested in languages. ${ }^{64}$

\section{Arabia in the North}

Peringer and Celsius thus make the case for Arabic using an established repertoire of arguments at the centre of which, as would be expected, theology is the leading discipline. The nobility of Arabic, its antiquity and purity, which set this language above all others, and its privileged role as a resource for scriptural exegesis were interlinked, and they were a sufficient incentive to establish Arabic studies in Sweden. A few years later the value of Arabic was promoted in the same style by Albert Schultens in his orations De utilitate linguae

59 Ibid., ch. 5, pp. 159-83.

$60 \quad$ Ibid., ch. 5, pp. 183-5. Peringer and Celsius are invoking the authorities of Johann Peter Buskagrius, with a public speech, entitled De usu linguarum in theologia, and Johannes Elai Terserus, with a disputation on teraphim, as the very first two Swedish Orientalists with Arabic language skills. Neither text has been published.

$61 \quad$ Ibid., ch. 6, pp. 193-9.

62 Hottinger, Smegma orientale, Liber I, ch. 7, pp. 107-201.

63 L. de Dieu, Animadversiones in Acta Apostolorum, Leiden, 1634, esp. ch. 7, pp. 49-80; id., Animadversiones sive Commentarius in quatuor evangelia, Leiden, 1631, esp. in Matthaeum, ch. 9, pp. 30-34.

64 Erpenius, Oratio de linguae arabicae praestantia et dignitate, fols $\mathrm{C}_{3}{ }^{\mathrm{r}}-\mathrm{D} 4^{\mathrm{v}}$; and C. Raue, Panegyrica secunda orientalibus linguis dicta, Utrecht, 1644, pp. 13-23. 
Arabicae and De linguae Arabicae antiquissima origine ${ }^{65}$ which were in every way paradigmatic for their period. ${ }^{66}$

However, the Historia linguae et eruditionis Arabum took on a distinctive cast through the national and patriotic focus that both authors wished to accord to Oriental studies; as we shall see, this too would have a lasting influence. From the mid-seventeenth century the Swedish national ideology of gothicism had established itself among large numbers of Swedish university professors. ${ }^{67}$ After disembarking from the Ark, Noah's descendants, the sons of Japheth, had travelled West and settled in Sweden, the original homeland of all the Nordic peoples, as had been maintained already by the Bishops of Uppsala, Johannes Magnus and Olaus Magnus. The Swedish peninsula had in this way become the parent of all European cultures, it being the place whence the Scythians, Amazons and Goths had conquered all of Europe in great migrations. Several works by Georg Stiernhielm (1598-1679) had already demonstrated that the earliest Gothic language must be directly related to Hebrew, ${ }^{68}$ due to the immigration of the Japhethites; indeed, as could be proved through long word-lists,

65 J. Braun - A. Schultens (resp.), De utilitate linguae arabicae in interpretanda sacra scriptura, Groningen, 1706, passim; id., Oratio altera de linguae Arabicae antiquissima origine, intima ac sororia cum lingua Hebraea cognatione, nullisque saeculis praeflorata puritate, Franeker, 1729 (reprinted 1732), passim; id. - J. Ratelband (resp.), Dissertatio philologica de convenientia admirabili dialecti arabicae cum hebraea in universo linguae ambitu, Leiden, 1740, there ch. 5, pp. 68-101 a commented translation of sura 1 into Hebrew. The extensive result of his exegetical work was A. Schultens, Animadversiones philologicae et criticae ad varia loca veteris testamenti, in quibus, ope praecipue linguae Arabicae, multa ab interpretibus nondum satis intellecta, illustrantur, Amsterdam, 1732.

66 On Albert Schultens, whose position towards Arabic was much more complex than it can be explained here, see the very useful remarks by J. Loop, 'Kontroverse Bemühungen um den Orient. Johann Jacob Reiske und die deutsche Orientalistik seiner Zeit', in Johann Jacob Reiske - Leben und Wirkung, Leipzig, eds H.G. Ebert and T. Hanstein, 2005, pp. 45-86 (54-61). For a survey of Schultens's writings see still F. Mühlau, 'Albert Schultens und seine Bedeutung für die hebräische Sprachwissenschaft', in Zeitschrift für die gesammte lutherische Theologie und Kirche, 31, 1870, pp. 1-21.

67 On the goticist ideology in Sweden in general see e.g. the surveys of I. Schmidt-Voges, De antiqua claritate. Gotizismus als Identitätsmodell im frühneuzeitlichen Schweden, Frankfurt, 2004, passim; J. Svenbro, 'L'idéologie gothisante et l'Atlantica d'Olof Rudbeck', in Quaderni di Storia, 11, 1980, pp.121-56, or S. Hansson, "The Lament of the Swedish Language: Sweden's Gothic Renaissance', in Renaissance Studies, 23, 2009, pp. 151-60.

68 On the figure of Georg Stiernhielm in general see P.R. Olofsson, Georg Stiernhielm. Diktare, domare, duellant. En levnadsteckning, Stockholm, 1998, passim; and already B. Swartling, Georg Stiernhielm. Hans liv och versamhet, Uppsala, 1909; and more recently e.g. K. Tarkiainen and Ü. Tarkiainen, Provinsen bortom havet. Estlands svenska historia 15611710, Stockholm, 2013, pp. 101-03. On Stiernhielm lexicographic projects J. Considine, Dic- 
it was possible to derive it directly from Hebrew. ${ }^{69}$ The aura of ancient Norse literature should therefore be correspondingly exalted. A few years before Peringer, the myth of the Hyperboreans had been related to the Swedish nation by Stiernhielm and Carl Lundius, who had situated the Hyperboreans' cult of Apollo in Scandinavia. ${ }^{70}$ The temple in Uppsala, as once described by Adam of Bremen, had been their temple and the worship offered in it had been the cult of a triad composed of Odin, Thor and Freya, a celestial cult based on the worship of sun, moon and earth. ${ }^{71}$ When, as was believed on the authority of the opening chapters of Snorre Sturluson's Heimskringla, the historical Odin had adopted the name of the god and migrated to Sweden from Asia Minor around the time of the birth of Christ, he had claimed this cult for himself. ${ }^{72}$ Sweden's great polyhistor Olaus Rudbeck the Elder (1630-1702), wanting to write a glorious prehistory for the Swedish empire, went a step further in his four-volume Atlantica, published in 1689-1704, which took the national ideology to its extreme. Rudbeck demonstrated with irrefutable erudition that Plato's Atlantis had been none other than the ancient Scytho-Gothic empire. ${ }^{73}$

tionaries in Early Modern Europe. Lexicography and the Making of Heritage, Cambridge, 2008, pp. 244-9.

69 G. Stiernhielm, Glossarium Ulphila-Gothicum linguis affinibus, per Franciscum Junium, nunc etiam Sveo-Gothica auctum et illustratum, Stockholm, 1670; and already id., Magog Aramaeo-Gothicus, Uppsala, 1650, see there e.g. fol. $\mathrm{B}_{2}{ }^{\mathrm{r}}$ on the 'Hall' of Odin, as derivated from the Hebrew word for 'tent', 'ahal'.

70 G. Stiernhielm, Anticluverius, sive Scriptum breve, Johanne Cluverio Dantisco-Borusso oppositum, Gentis Gothicae originem et antiquissimam in Scandia vel Scandinavia sedem vindicans, Stockholm, 1685, Dissertatio de Hyperboreis, pp. 135-37; and C, Lundius, Zalmoxis primus Getarum legislator, Uppsala, 1683 , ch. 3 , § 11, pp. 78-84.

On the golden temple of Uppsala and its timeless dignity, as exposed already by the Magnus brothers see e.g. M.E. Ruggieri, 'Gli idoli del tempio di Uppsala: tradizione ed ermeneutica in Johannes e Olaus Magnus', in C. Santini, I fratelli Giovanni e Olao Magno. Opera e cultura tra due mondi, Rome, 1999, pp. 261-308.

72 S. Sturluson, Heims Kringla, eller Nordländske Konunga Sögor, transl. J. Peringskiöld the Elder, Stockholm, 1697, Old Norse and Latin, ch. 2-8, pp. 2-10.

On Rudbeck's life see e.g. D. King, A True Story of Genius, Madness, and an Extraordinary Quest for Lost World, New York, 2005, there on the 'Atlantica' pp. 143-6, pp. 161-5. For a survey of the 'Atlantica' see G. Eriksson, The Atlantic Vision. Olaus Rudbeck and Baroque Science, Canton, 1994, pp.13-86; and id., Olaus Rudbeck 1630-1702. Liv, lärdom, dröm i barockens Sverige, Stockholm, 2002, pp. 279-496. In addition e.g. I. Schmidt-Voges, De antiqua claritate, pp. 177-90, Tero Anttila, 'East of Atlantis - Ancient Finland and its Inhabitants in Olof Rudbeck the Elder's Atlantica', in Itämeren itälaidalla II, eds K. Alenius a, A. Honkola, Rovaniemi, 2009, pp. 39-56 (43-51); or already A. Ellenius, 'Olaus Rudbecks Atlantiska Anatomi', in Lychnos, 1959, pp. 40-52; and esp. J. Nordström, De yverbornes ö. Sextonhundratalsstudier, Stockholm, 1934, pp. 136-54. 
At its heart had stood the golden temple of Uppsala, whose celestial cult, as Rudbeck proved in detail, had become the archetype of all the mythologies of the ancient world. The Yule festival held in archaic Sweden at the winter solstice to celebrate the return of the sun was the paradigm of all solar and vegetation cults of the ancient world, whether they took on the form of Persephone, Cybele or Dionysos, all of whom were just variations on the drama of the slain god Balder. Its caste of priests, the caste of Druids established by Odin, had become the model for all priestly castes. ${ }^{74}$ Rudbeck had attempted to trace all the divine cults found in the Greco-Roman world back to an Old Norse substrate, basing his case on the Edda. Since the 1680 , Swedish scholars like Jacob Reenhielm and Olaus Verelius had begun to translate into Latin the remains of saga literature, such as the 'Hervara Saga' or 'Egil's Saga einhenda,,75 and commented on them in the same spirit as Rudbeck, viz. as witnesses to a primeval tradition that illuminated the Old Norse solar cult. ${ }^{76}$ One of the most important members of this national-minded translation project was Peringer's younger brother, Johan Peringskiöld the Elder (1654-1720), ${ }^{77}$ who provided Sweden not only with a Latin version of the Heimskringla and a translation of the Norse variant of the saga of Dietrich and the Nibelungen, ${ }^{78}$ but, together

74 O. Rudbeck the Elder, Atland eller Manheim, dedan Japhetz afkomne, de förnemste Keyserlige och Kungelige Slecht. Atlantica sive Manheim, vera Japheti posterorum sedes ac patria, 4 vols, Uppsala, 1679-1702, there on the solar cult with all its branches and derivations vol. 2, Latin and Swedish, ch. 5, pp. 135-436.

75 On the early modern Latin saga translations in Sweden see K. Busch, Großmachtstatus und Saga-Interpretation - die schwedische Vorzeitsagaeditionen des 17. und 18. Jahrhunderts, Diss. Digital. University Library Erlangen, 2004. For a useful survey of Swedish 17th and 18th century antiquarism and its methological approach see in addition J. Widenberg, Fäderneslandes antikviteter: etnoterritoriella historiebruk och integrationssträvanden $i$ den svenska statsmaktens antikvariska verksamhet ca 1600 - 1720, Uppsala, 2006, esp. pp. 105-41; M. Legnér, Fäderneslandets rätta bekrivning. Mötet mellan antikvariskforskning och ekonomisk nyttokult i 17oo-talets Sverige, Helsinki. 2004, esp. pp. 48-83; and S. Blocher, Altertumskunde und Sammlungswesen in Schweden von den Anfängen im Mittelalter bis zur Regierungszeit Gustavs II. Adolf, Frankfurt. 1993, pp. 199-210.

76 See e.g. O. Verelius, Hervarar Saga på gammal Götska, Uppsala, 1672, ch. 1, pp. 21-3, or ch. 4, pp. 6o-66, or P.Salanus, Fostbroedernas Eigles Och Asmunds Saga-Fortissimorum pugilum Egilli et Asmundi Historia, Uppsala, 1693, Notae, pp. 156-6o.

On Peringskiöld's translations Busch, Großmachtstatus, pp.121-35, pp. 203-20; or K. Schier, 'Literatur als historisches Argument: Einige Bemerkungen zum Nachwirken Snorris in Skandinavien vom 17.-19. Jahrhundert', in Snorri Sturluson. Beiträge zu Werk und Rezeption, ed. H. Fix, Berlin, 1998, pp. 181-229, here pp. 201-6.

78 J. Peringskiöld, Vita Theoderici regis Ostrogothorum et Italiae autore Joanne Cochlaeo Germano, cum additamentis et annotationibus, quae Sveo-Gothorum ex Scandia expeditiones 
with his son Johan the Younger (1689-1725), also an extensive census of the Swedish runic inscriptions. ${ }^{79}$

At various points in their Historia, Peringer and Celsius take account of this national ideology, which in 1694 was still a long way from its zenith. When discussing the origin of the decimal system and the numeral notation in use today, they admit that the Indians can rightly claim responsibility for the 'Arabic' numerals. ${ }^{80}$ A similar argument had already been made by Erpenius and Wasmuth in their Arabic grammars; ${ }^{81}$ Georg Welsch had also treated the topic in detail in his Ruzname. ${ }^{82}$ But who could say, argued Peringer, whether it had not in fact been the Scythians, the mother-people of the Goths, who were due the credit for discovering the numerals? ${ }^{83}$ Matters were similar with the practice of writing as a whole and the first writing materials. Job had wanted to carve his writings in stone; 84 and Athanasius Kircher had discovered what was perhaps the oldest Semitic inscription, carved into Mount Horeb. ${ }^{85}$ But was this primitive form of writing not the same as that of the runestones and their script? And especially similar, Peringer and Celsius observe, to that minimal and perhaps earliest - almost cuneiform - variant, which Olaus Celsius's father, Magnus Celsius (1621-1679), had found in Helsingland. Was this not perhaps evidence of an inner affiliation? ${ }^{86}$ When Celsius in 1702 returned to the topic of the runestones of Helsingland, he managed to give even greater weight to the parallels. ${ }^{87}$ Flavius Josephus had recounted how the descendants of Seth had carved their celestial knowledge on stones to save it from the deluge; the Jews had carved their Commandments on tablets of stone or, like Jacob in

et commercia illustrant, Stockholm 1699; id., Wilkina-Saga, aller Historien om Könung Thiderich af Bern, och seins Kämpar, samt Niflunga Sagan, Stockholm, 1715.

79 J. Peringskiöld, Monumentorum Sveo-Gothicorum liber Primus, Uplandiae partem primariam Thiundiam continens, cum Antiquitatibus ac Inscriptionibus quae Cippis et Rupibus, vel Tumbis incisae passim reperiuntur, Stockholm, 1710, there on the solar cult of Uppsala ch. 2, pp. 134-62.

8o Peringer - Celsius, Historia linguae et eruditionis Arabum, ch. 1, pp. 19-22.

81 T. Erpenius, Grammatica arabica, Leiden, 1613, Liber I, ch. 1, p. 11; M. Wasmuth, Grammatica arabica, Amsterdam, 1654, ch. 1, sectio 1, p. 4.

82 Welsch, Commentarius in Ruzname, p. 72.

83 Peringer - Celsius, Historia linguae et eruditionis Arabum, ch. 1, pp. 18-19.

84 Job, 19:23-24.

85 A. Kircher, Prodromus coptus sive Aegyptiacus, Rome, 1636, ch. 8, pp. 201-19.

86 Peringer - Celsius, Historia linguae et eruditionis Arabum, ch. 1, pp. 14-15.

87 O. Celsius - O. Flodman (resp.) - M. Thelaus (resp.), Sunaita runr sive Oreades Helsingicae redivivae, 2 vols, Uppsala, 1710, vol. 1, Pars I, ch. 4-5, pp. 15-23. 
Bethel, had set up standing stones. ${ }^{88}$ Just so, Celsius pointed out, had the men of the North proceeded from the earliest times, as one could learn from the Heimskringla. ${ }^{89}$ In the Historia, Peringer and Celsius are able to adduce even more parallels between Arab culture and the Old Norse homeland. Hardly any language had produced more eloquent poets than Arabic, as had been shown already by Erpenius and Johann Fabricius Dantiscanus. ${ }^{90}$ Did not these poets, with their intricate metaphors, their satirical wit and the often agonistic character of their delivery, correspond to the Norse skaldic poetry, the vast antiquity of which was self-evident to every committed Gothicist? ${ }^{91}$ With satisfaction Peringer and Celsius finally observe that the Arabic geographer al-Idrīsì, whose work had been translated into Latin by Gabriel Sionita a few years previously, ${ }^{92}$ already had a sound knowledge of Sweden and Finland and had noted not only Kalmar and Sigtuna, the metropolis founded by Odin, but also Tavastia, the Finnish region of Häme. ${ }^{93}$

\section{Peringer and Celsius as Swedish Arabists}

It was already pointed out by Hans-Joachim Schoeps that Gustaf Peringer Lillieblad became the guiding figure for a whole generation of Swedish Orientalists who took their cue from Buskragius and Terser, both of whom were mentioned by Peringer. Across a period of around three decades scholars like

88 F. Josephus, Opera, ed. H. St. J. Thackeray, 9 vols, Cambridge, MA., 1961, Jewish Antiquities, vol. 4, Book I, § 3, Greek and English, pp. 30-33.

89 Celsius - Flodman - Thelaus, Sunaita runr sive Oreades Helsingicae, vol. 1, Pars I, ch. 6, pp. 23-6. Athanasius Kircher, informed about the Helsingland-runes, was not willing to identify letters at all, see O.Celsius, De runis helsingicis ad virum illustrem Antonium Magliabechium epistola, Rome, 1698 , fol. A2 ${ }^{\mathrm{v}}$.

Erpenius, Oratio de linguae arabicae praestantia et dignitate, fols $\mathrm{D}_{3}{ }^{\mathrm{r}}-\mathrm{D} 4^{\mathrm{r}}$; Fabricius, Specimen arabicum, pp. 169-82, Pococke, Specimen Historiae Arabum, Notae, pp. 158-61. On metrics Peringer - Celsius, pp. 117-19, are giving some extracts taken from Samuel Clarke, Scientia metrica et rhythmica, seu Tractatus de prosodia arabica, Oxford, 1661. Peringer - Celsius, Historia linguae et eruditionis Arabum, ch. 3, pp. 115-17.

92 G. Sionita, Geographia Nubiensis, id est accuratissima totius orbis in septem climata divisi descriptio, Paris, 1619, Clima septimum, pars 5, pp. 274-75. The Arabic text, used by Peringer, appeared as Kitāb Nuzhat al-mushtāq, Rome, 1592, Reprint Frankfurt, 1992, see there Climate VII, Pars 5 (without pagination). For a modern commented edition see al-Idrīsī, La Finlande et les autres pays baltiques orientaux, ed. O.J. Tallgren-Tuulio and A.M. Tallgren, Helsinki, 1930 , there pp. $3{ }^{3-35}$, and see on Sigtuna, Tavastia and Kalmar in the commentary, p. 44, pp. 48-9. 
Johannes Palmrooth, Laurentius Normann, Daniel Lundius, Carolus Schulten, Georg Wallin, Eric Fahlenius, Anders Boberg, Michael Enemann and Eric Benzelius the Younger brought about a flourishing of Swedish Oriental studies that would never again be reached at the universities of Uppsala, Lund, Turku, Greifswald, Tartu and Pernau. The result of their work was, primarily, a thriving practice of translation from Hebrew, conducted in monographic works and disputations and involving especially Maimonides, Ibn Esra and Abravanel, though it also found room for less well known authors such as Jehuda Lebh ben Hillel. Not all the products of this period made their way into print: kabbalistic texts, in particular, such as an extensive Zohar anthology and excerpts from the 'Sefer Gale Razeia', circulated only in manuscript. In addition to the Latin translations, the number of disputations treating rabbinical questions and biblical realia runs into three digits. These works, too, make generous use of Hebrew literature and, as Schoeps showed, they often draw even on obscure texts in the original language. ${ }^{94}$

94 On Semitic and especially the Hebrew studies at the Swedish universities in general see the surveys of Schoeps, Philosemitismus im Barock, Religions- und geistesgeschichtliche Untersuchungen, Tübingen, 1952, pp. 134-62; and B. Roling, 'Erlösung im angelischen Makrokosmos. Emanuel Swedenborg, Die Kabbala denudata und die schwedische Orientalistik', in Morgen-Glantz, 16, 2006, pp. 385-457 (397-420). On semitic studies in Uppsala in 17th and 18th century J. Eskhult, Andreas Norrelius' Latin Translation ofJohan Kemper's Hebrew Commentary on Matthew, Uppsala, 2007 (53-63); B. Lindberg, 'Filosemitism och biblicism - om synen på det judiska i det karolinska Sverige', in Csató - Gren-Eklund Sandgren, En resenär, pp. 143-63 (146-61); G. Bäärnhielm, 'Orientalistiken i Sverige fram till 1720-talet', in Csató - Gren-Eklund - Sandgren, En resenär, pp. 39-87; Marsha Keith Schuchard, Emanuel Swedenborg, Secret Agent on Earth and in Heaven.Jacobites, Jews, and Freemasons in Early Modern Sweden, Leiden, 2012, pp. 14-36; F. Rundgren, 'Semitic Languages', in Uppsala University 500 Years, vol. 6, Faculty of Arts at Uppsala University. Linguistics and Philology, Uppsala, 1976, pp. 99-112 (100-08); Annerstedt, Uppsala Universitets Historia. Andra Delen, vol. 1, pp. 314-16, and vol. 2, pp. 290-7, Tredje Delen, vol. 1, pp. 11924, and vol. 2, pp. 390-405; and earlier K.U. Nylander, 'Semitiska studier i Sverige under flydda tider', in Ny svensk tidskrift för kultur- och samhällfrågor, populär vetenskap, kritik och skönliteratur, 10, 1889, pp. 179-208, pp. 329-68. On Oriental and mainly Hebrew studies in Turku see K. Karttunen, 'Lähteitä orientalistiikan ja Vanhan testamentin eksegetiikan historiaan 1640-1828', in Suomalaisen eksegetiikan ja orientalistiikan juuria, eds I. Antola and H. Halén, Helsinki, 1993, pp.163-202, there a survey of all dissertations pp. 163-79; id., Itää etsimässä. Eurooppalaisen Aasian-tutkimuksen vaiheita, Helsinki, 1992, pp. 48-51; and especially id., Moseeksen kirjoista kungfutselaisuuden klassikoihin ja Jerusalemista Siperian tundralle. Aasian-tutkimuksen vaiheet Suomessa, Helsinki, 2011, pp. 13-182. On the role of Semitic studies in Tartu/Dorpat and Pärnu/Pernau see first of all von Rauch, Die Universität Dorpat, pp. 348-54; and K. Karttunen, 'Linguarum professio in Academia Gustaviana in Tartu (Dorpat) and Academia Gustavo-Carolina in Pärnu 
In Sweden there was great interest in the Kabbala which, from his arrival in Sweden in 1698, was promoted by one man, a convert and former follower of Sabbatai Zevi, Moses ben Ahron, who had given himself the name Johann Kemper. As we shall see, this special standing of the Kabbala in Sweden would not leave Arabic studies at the Swedish universities untouched. Kemper was responsible for some works on the Cabala christiana, including a series of Zohar excerpts and a Hebrew translation of the Gospel of Matthew, which he commented upon in the tradition of the Christian Kabbala. ${ }^{95}$ Kemper found an enthusiastic student in a contemporary of Olaus Celsius, the Uppsala Orientalist and librarian Anders Norrelius (1679-1749), who, in several treatises, in turn adapted Kemper's works and translated them into Latin. ${ }^{96}$ Even a quick look at Norrelius's texts shows that a few basic ideas that had long been established in the tradition of the Christian Kabbala were deployed to adapt the kabbalistic sefirot system to Christianity. For Norrelius, Christ corresponded to the mediating angel of the Enoch tradition, Metatron and El Shaddai, the Son of God and incarnate Logos. At the same time, within the ten sefirot the Saviour could be matched to the sefira yesod, in which the sefirot tif'eret and malkhut were united. This union of three sefirot in one, Norrelius believed, reflected the triad of the upper sefirot, which bore all the attributes of the

(Pernau) in Estonia', in Nordisk Judaistik, 16, 1995, pp. 65-74; and earlier A. Bulmerincq, 'Orientalistika õpingud Tartu rootsiaegses ülikoolis', in Usuteadusline Ajakiri, 3, 1932, pp. 39-44.

95 On the life and teachings of Johan Kemper, whose longlasting influence can still be seen in the works of Jonas Hallenberg, as will be demonstrated below, and his approach to Oriential studies Eskhult, Andreas Norrelius' Latin Translation, pp. 64-72; Schoeps, Philosemitismus im Barock, pp. 92-133; S. Asulin, 'Another Glance at Sabbateanism, Conversion and Hebraism in Seventeenth-Century Europe: Scrutinizing the Character of Johan Kemper in Uppsala, or Moshe, Son of Aharon of Krakow (Hebrew)', in The Sabbatean Movement and its Aftermath. Messianism, Sabbateanism and Frankism (Jerusalem Studies in Jewish Thought 16/17), 2 vols, ed. R. Elior, Jerusalem, 2001, pp. 423-70 (427-70); E.R. Wolfson, 'Messianism in the Christian Kabbalah of Johann Kemper', in Jewish Messianism in the Early Modern World, eds M.D. Goldish and R.H. Popkin., Dordrecht, 2001, pp. 139-87. On Kempers commentary on Matthew see esp. M. Eskhult, "Rabbi" Johan Kemper's skrifttolkning: en maktpåliggande frihet', in Ordets makt och tankens frihet: Om språket som maktfaktor, ed. R.B. Andersson, Uppsala, 1999, pp. 159-68; and Eskhult, Andreas Norrelius'Latin Translation, pp. $73^{-81}$.

96 On the figure of Anders Norrelius Schoeps, Philosemitismus im Barock, p. 98, pp. 107-13, p. 116, pp. 143-6; Roling, 'Erlösung', pp. 403-7; and already Nylander, 'Semitiska studier', pp. $343-4$. 
Christian Trinity. ${ }^{97}$ It was perhaps unusual in Norrelius's work that this Uppsala Orientalist, who had also demonstrated his knowledge of Arabic in a study of the bird names in Scripture, ${ }^{98}$ made extensive use of the classics of antiQur'anic polemic, above all the Prodromus Alcorani of Lodovico Maracci, in order to search the Qur'an, too, for evidence of belief in the Trinity. ${ }^{99}$

Peringer and Celsius at first glance do not seem to move far outside the mainstream of Swedish Hebrew studies. ${ }^{100}$ Peringer produced a whole series of Latin translations, including the Mishna tractates 'Avoda Zara' and 'Tamid', ${ }^{101}$ which he had done already as a student in Altdorf, and excerpts from the Mishne Torah of Maimonides. ${ }^{102}$ The treatises and disputations addressed well known topics that were often discussed subsequently, too, such as the Urim

A. Norrelius, Phosphorus orthodoxae fidei veterum Cabbalistarum testimonia de sacrosancta trinitate et Messia Deo et homine ex pervetusto libro Sohar deprompta, Amsterdam, 1720, pp. 6-7, pp. 43-7; id., Någre utvalde Bevis, Tagne utur Sohar, fom är Judarnes åldsta och vårdesta Utlågning öfver Mosis Böcker, at deras Förfåder, som fordom lefde under Gamla Testamentets tid, haft samma Lära och Tro, om det Guddomeluga Väsendet: om Messia, eller Jesu Christo: och hans Medlare-ämbete, som vi Christne det nu hafve, Uppsala, 1747, Iv. Beviset, pp. 8-10, vir. Beviset, pp. 13-16; id., Hebreiska oration vid Jubelfesten $i$ Uppsala den 16 Juni 1730, ed. and transl. (into Swedish) K.V. Zetterstéen, Leipzig, 1923, Hebrew pp. 26-30, Swedish, pp. 48-51; and in the Latin translation of Johan Kemper by Norrelius e.g Eskhult, Andreas Norrelius' Latin Translation, p. 351, p. 352, pp. 356-7.

A. Norrelius, Schediasma de avibus Arbeh, Solam, Chargol, Chagab Israelitis in cibum concessis, Amsterdam 1720, id., Diatriba de avibus de esu licitis quam codice sacro, Talmudico Chullin, et naturae scrutinio in ulteriorem locorum Levit. XI et Deut. XIV illustrationem, Uppsala, 1746, there e.g. p. 3, p. 21, p. 23, pp. 6o-61, p. 69.

99 Norrelius, Phosphorus orthodoxae fidei, p. 3, pp. 9-10, pp. 14-15.

100 On Peringer's Hebrew studies see beside Schoeps now M. Eskhult, 'Peringer som hebraist', in Csató - Gren-Eklund - Sandgren, En resenär, pp. 127-39.

101 G. Peringer, Masekhtot 'Avoda zara ve-Tamid paraphrasi Latina redditi, quorum primus agit de Idolatria, alter de Sacrificio iugi, quod olum in Templo Hierosolymitano quotidie offerebatur, Altdorf, 1680. As Peringer stresses in his introduction (without pagination), Wagenseil was his teacher, but his real inspiration was Edward Pococke, ornamentum huius saeculi. The book was dedicated to Queen Ulrika Eleonora.

102 G. Peringer, Officium Messiae Judaici, hoc est R. Mosis Maimonis Tractatus de regibus caput undecimum, Uppsala, 1692; and e.g. id. - J. Florander (resp.), R. Mosis Maimonidae Tractatus de primitiis cap. sextum et septimum, quae ex Hebraeo in sermonem Latinum conversa, Uppsala, 1695, together with further disputations on chapters of the same treatise. Peringer's bibligraphical work culminated in G. Peringer - J. Ritterhus (resp.), De cura litteraturae hebraicae, praecipie inter Europaeos, breviter delineata in dissertatione graduali, Uppsala, 1688. 
and the Thummim, ${ }^{103}$ the Nazarites, ${ }^{104}$ the scapegoat, ${ }^{105}$ tefilin, ${ }^{106}$ the Tabernacle, ${ }^{107}$ washing the hands, ${ }^{108}$ the Jubilee ${ }^{109}$ or Jonah's gourd. ${ }^{110}$ An unusual but maybe today well-known point in Peringer's work in Jewish studies was his frequently affirmed interest in the Karaites, whom he sought out in person in Lithuania during a lengthy journey in $1690 .{ }^{111}$ The results of his expedition, which consisted primarily in a collection of manuscripts, were reported in letters, including one that was published, to Hiob Ludolf, with whom he was in close contact. ${ }^{112}$ The journey resulted in no other publications, but Peringer devoted a series of lectures to his experience in Lithuania. In the following

103 G.Peringer - J. Lechander (resp.), Urim et Thummim, Uppsala, 1684.

104 G.Peringer - C. Jernfeld (resp.), De Nasiraeis tractatus Hebraeo-philologicus, Uppsala, 1683 .

105 G.Peringer - H. Stridsberg (resp.), De Asasele seu hirco emissario dissertatio philologica, Uppsala, 1683 .

106 G.Peringer - N. Swebelius (resp.), Dissertatio philologica de tephilin seu phylacteriis, Uppsala, 1690.

107 G. Peringer - P. Tillaeus (resp.), Vikuah 'al mishkan ohel mo'ed sive Historiola tabernaculi mosaici, Uppsala, 1688.

108 G.Peringer - A. Wijbjörnsson (resp.), Disputatio philologica Netilat yadayim seu lotionem manuum secundum morem hebraeorum, Uppsala, 1688.

109 G.Peringer - O. Hernodius (resp.), De anno Judaeorum jubilaeo, Uppsala, 1685.

110 G. Peringer - D. Trautzel (resp.), Dissertatio philologica de kikajon Jonae, Uppsala, 1691.

111 On Peringer's travellings in Lithuania see first S. Szyszman, 'Gustaf Peringers Mission bei den Karäern', in Zeitschrift der Morgenländischen Gesellschaft, 102, 1952, pp. 215-28; and now esp. E.Á. Csató, 'Caraimica upsalensia', in Csató - Gren-Eklund - Sandgren, En resenär, pp. 181-213. Peringer's journey has received great attention also in Lithuania itself, see e.g. A. Balulis - S. Mikulionis - A. Miškinis, Trakų miestas ir pilys, Vilnius, 1991, p. 114; and H. Kobeckaitè, Liutuvos Karaimai, Vilnus, 1997, p. 36, p. 51. When the Swedish King Carl xvi Gustaf was visiting Trakai, the Karaite capital in Lithuania, in the year 1992, where he was warmly welcomed by the Karaite community of the city, according to the Lithuanian Web-Portal 'Mes-karaimai' (<http://trakietis.balsas.lt/traku-naujienos/nauji enos/mes---kaaimai>, written by Romualdas Tinfavičius), it was noted that the King was visiting Trakai 300 years after Peringer's journey, which had been initiated by his royal predecessor Carl XI, and demonstrated the great history of Swedish interest in their life.

112 G. Peringer, 'Epistola ad Iobum Ludolphum de statu Karraitarum in Lithuania', in Monatliche Unterredungen Einiger Guter Freunde von Allerhand Büchern und Anderen Annemlichen Geschichten, Nürnberg, 1691, pp. 572-4. A collection of Peringer's letters written to Hiob Ludolf, but including also Erik Benzelius and Bengt Gabrielsson Oxenstierna is reproduced in Csató, 'Caraimica upsalensia', pp. 184-93, pp. 201-12. On Hiob Ludolfs close contacts to Sweden see already S.J.C. Lindqvist, 'Hiob Ludolf och Sverige', in Donum Grapeanum. Festskrift tillägnad överbibliothekaren Anders Grape på sextiofemårsdagen den 7 mars 1945, Uppsala, 1945, pp. 605-25. 
period, Olaus Celsius probably saw himself primarily as a scholar of Hebrew. He and his respondents presented, among other things, studies on the Tractate 'Sanhedrin',113 synagogues, ${ }^{114}$ the Hebrew language in general, ${ }^{115}$ Hebrew coinage, ${ }^{116}$ Samson's foxes, ${ }^{117}$ the Jewish oath, ${ }^{118}$ the crossing of the Red Sea, ${ }^{119}$ the Mount Sinai, ${ }^{120}$ the 'Ma'ase Bereshith,, ${ }^{121}$ the Hebrew law of war, ${ }^{122}$ Jewish laws on washing, ${ }^{123}$ Rabbi Gamliel and his possible relation to Christianity, ${ }^{124}$ the Samaritans, ${ }^{125}$ Jewish converts, ${ }^{126}$ and ambitious studies of Maimonides, which were accompanied by a richly annotated catalogue of his works. ${ }^{127}$

113 O. Celsius - N. Hedenius (resp.), Synedrium judaicum dissertatione philologica delineatum, Uppsala, 1709 .

114 O. Celsius - P. Eekman (resp.), Batte kenesiyyot sive De synagogis dissertatio gradualis, Uppsala, 1712 .

115 O. Celsius - J.J. Montelius (resp.), 'Al leshon ha-qodesh sive de lingua sancta disputatio philologica, Uppsala, 1712.

116 O. Celsius - E.P. Sahlmann (resp.), Dissertatio gradualis de antiquis Hebraeorum nummis, Uppsala, 1719 .

117 O. Celsius - E. Bråmann (resp.), Exercitium academicum de vulpibus Simsonis, Uppsala, 1719 .

118 O. Celsius - E. Rudman (resp.), Exercitium academicum Shebuot yehudim sive iuramenta Judaeorum, Uppsala, 1727.

119 O. Celsius - O.J. Telin (resp.), De transitu Israelitarum per mare rubrum philologema, Uppsala, 1715 .

120 O.s Celsius - N. Altenius (resp.), Har Sinaj seu Mons Sinai brevi dissertatione delineatus, Uppsala, 1717 .

121 O. Celsius - J. Landberg (resp.), Ma'ase bareshit opera prima divina dissertatione philologica explicaturus, Uppsala, 1718.

122 O. Celsius - J.Wallinus (resp.), Disputatio philologica de legibus hebraeorum bellicis, Uppsala, 1722.

123 O. Celsius - A.A. Leufstadius (resp.), Dissertatio philologica de lotionibus Ebraeorum, Uppsala, 1727.

124 O. Celsius - E. Siberg (resp.), Rabban Gamliel Senior, Uppsala, 1715, there on his role in Christianity § 6, pp. 28-31.

125 O. Celsius - M.L. Schepner - I. Peldan (resp.), Specimen academicum de templo Samaritanorum in Garizim, Uppsala, 1722; and O. Celsius - E. Frondel (resp.), Natales linguae literarumque Samaritanorum, Uppsala, 1717.

126 O. Celsius - J. G.Ratzki, De judaeis conversis, eorumque in rem christianam aut literariam historiola, Uppsala, 1714 .

127 O. Celsius - J. Unaeus (resp.), Specimen academicum de Rambam seu R. Mose Maimonide, Uppsala, 1727, there on the writings of Maimonides $\S \S 9-11$, pp. 20-35, §§ 19-23, pp. 57-72. Celsius, § 6, pp. 10-14, stresses also Maimonides strong connection with Arab philosophy. In addition e.g. O. Celsius - L. Hellmann (resp.), Halikot kela'im sive R. Mosis Maimonidae tractatus de miscellis tria capita, Uppsala, 1713. 
But what was the later fate of Arabic studies, the project initiated by Peringer and Celsius in 1694? In the same year as the Historia, Peringer treated the Hijra of the Prophet at length, and by drawing on Elmacinus he reported and commented upon the special role of the city of Mecca and compared the Arabic dating era with the Christian and Jewish ones. ${ }^{128}$ One study, certainly prompted by scholars like Gabriel Sionita und Abraham Ecchellensis, had already been devoted to the Maronites. ${ }^{129}$ For a wider public the Uppsala professor translated into Swedish the 'Dream book' of Muhammed b. Sīinn, which had long been circulating in Europe. ${ }^{130}$ Arabic is also brought into disputations by Peringer on Rabbinic topics. He briefly addresses the Arabic names of gods in his treatise on the tetragrammaton. ${ }^{131}$ In his study of the Hebrew protective amulettes and sigilla, which brims with parallels from both folklore and kabbalistic sources, ${ }^{132}$ Peringer does not omit to include variants from Arabic occultism, which could have been an important source for Jewish talismanic magic. ${ }^{133}$ His authority for this was Henning Henningsen's monumental study, Muhammedanus precans, hitherto largely overlooked, which provided information about comparable rituals. ${ }^{134}$ When in 1696 Peringer presented in translation a catechism that had been produced in an Algonquian language for the Indians of Swedish Virginia, his observations included not only the fact that the Swedes had occupied the area seven hundred years earlier through the Vinland voyages, ${ }^{135}$ but also remarks on the number of Bible translations that had been made into Oriental languages and on whether the many Indian idioms might match up to Hebrew in their poetic acoustic patterns. ${ }^{136}$

128 G. Peringer - A. Orostander (resp.), Dissertatio de Hegira Muhammedis, Uppsala, 1694, §§ $5^{-8}$, pp. 9-21. See e.g. Elmacinus, Historia saracenica, Liber I, ch. 1, pp. 5-27; Hottinger, Historia orientalis, Liber IV, ch. 4, pp. 260-70.

129 G. Peringer - J. Jäger (resp.), Dissertatio historica de Maronitis, Uppsala, 1691.

130 G.Peringer, Ny Apomasaris dröm-book, thet är en upsats på allehanda slags drömmer hwilka man icke allenast effter the indianers, persers och aegyptiers lära, har befunnit sanne, utan och af långlig förfarenheet och noga upteknande förmärkt, ofehlbart, Stockholm, 1701 .

131 G. Peringer - J.E. Klinthe (resp.), De glorioso et reverendo nomine Dei Tetragrammato Jehova dissertatio hebraeo-philologica, Uppsala 1682, ch. 3 , § 6, fols $\mathrm{D}_{2}{ }^{\mathrm{v}}-\mathrm{D}_{2}{ }^{\mathrm{r}}$.

132 G. Peringer - L.J. Weslander (resp.), De amuletis Hebraeorum dissertatio, Stockholm, 1685, ch. 3, pp. 39-55.

133 Ibid., ch. 2 , $\S \S 3-4$, pp. 15-17, § 7, pp. 20-21, § 9, pp. 23-4.

134 Henningsen, Muhammedanus precans, e.g. pp. 100-01, pp. 112-14, pp. 378-80.

135 J. Campanius Holm, Lutheri Catechismus, öfwersatt på America-Virginske Språket, Stockholm, 1696, Preface, fols a $6^{\mathrm{r}}-\mathrm{a} 7^{\mathrm{r}}$.

136 Ibid., Preface, fols a2 ${ }^{\mathrm{r}}-\mathrm{a} 2^{\mathrm{v}}$. 
However, Peringer's interest in Arabic continued to be attracted above all by the celestial cult that he himself had declared to be central to ancient Arab life. At least indirectly Peringer was here playing into the hands of the Rudbeckians, who had judged these celestial cults to be derivatives from or preludes to the Trinity of Uppsala. ${ }^{137}$ Peringer provided the realia from the history of religion that could further illustrate and fill out Rudbeck's grand synthesis. The founder of the worship of the celestial bodies was Noah's son Ham, as the Uppsala professor established in a special study on the topic; Ham's descendants had taught astronomy to, among others, Zoroaster in Bactria. ${ }^{138}$ Knowledge of the zodiac and large parts of mathematics, but also the cult of Isis and Osiris, representing in bodily form the Sun and the Earth, were established by Ham in Egypt. ${ }^{139}$ Other representatives of this religion of the celestial bodies were the Sabaeans, whose existence would have been seen as a challenge above all by the Jews. The question of whether Zoroaster was also responsible for their rites is left open by Peringer. ${ }^{140}$ The customs and stellar cults of the Sabaeans are explicated by the Uppsala scholar and his respondent, the later professor Daniel Lundius, primarily by drawing on Pococke, Hottinger and of course Maimonides himself, who, for both of them, explicitly confirms the immense antiquity of Sabaean cult practice. ${ }^{141}$ For Peringer, the Magi follow on from the Sabaeans. Even their name, as Peringer stresses, is indirectly owed to Arabic, and originates in the root $j-s-s$, a word for explorari. ${ }^{142}$ They too had worshipped sun and stars in a similarly complex ritual to that of the Sabaeans, as had been stressed already by the philosophus Arabs Job. ${ }^{143}$ A further cult of

137 On the late academical reception of Rudbeckianism in general see T. Frängsmyr, Svensk idéhistoria. Bildning och vetenskap under tusen år, 2 vols, Stockholm, 2000, vol. 1, pp. 3235; Lindroth, Svensk Lärdomshistoria, vol. 3, pp. 643-53; and especially, with a special focus on Finland, B. Roling, 'Von der Magie zur Poesie: Universalmythen in der finnischen Ethnogenese des 18. Jahrhunderts', in Die Enzyklopädie der Esoterik, eds A.B. Kilcher and P. Theisohn, Munich, 2010, pp. 213-56.

G. Peringer - E. Halenius (resp.), De Chamo scientiarum auctore dissertatio, Uppsala, 1694, Thesis 2, pp. 4-7.

139 Ibid., Thesis 7, pp. 20-22, Thesis 9, pp. 25-8. See in addition also G. Peringer - J.D. Wingius (resp.), De Sanchoniathone dissertatio, Uppsala 1686, Membrum III, ch. 7, pp. $20-25$.

140 G. Peringer - D. Lundius (resp.), Emunat ve-daat ha-tsoveh. De Zabiis dissertatio philologica, Uppsala, 1702, § 2, pp. 3-6.

$141 \quad$ Ibid., $\S \S 9-12$, pp. 20-26.

142 G. Peringer - J. Arborelius (resp.), Exercitatio academica de Magis Persarum, Uppsala, 1694, Thesis 1-2, pp. 1-5.

143 Ibid., Thesis 5, pp. 10-12. See Job 31:26; and e.g. de Dieu, Animadversiones sive Commentarius in quatuor evangelia, in Marcum, ch. 2, pp. 3-4, and Alfraganus, Elementa astronomica, Notae, p. 35 . 
light was maintained in the temple of Gades, as Peringer explains in a followup study. ${ }^{144}$ The end of the series is formed by a disputation on heliolatry in general. Peringer summarizes in almost encyclopaedic scope all known solar cults of the ancient world, and finally moves straight to Olaus Rudbeck, who had presented sufficient arguments, Peringer stresses, to prove the foundational role of the stellar cult in Uppsala and the triad of Odin, Thor and Freya. ${ }^{145}$

Olaus Celsius's later work in Arabic studies seems less speculative and more motivated by the exegetical role of Arabic, which he himself had ranked so highly. Celsius treated the god Moloch, ${ }^{146}$ the role of the Arabs in Spain, ${ }^{147}$ the place of paradise ${ }^{148}$ and of Islam in India, which he sketched out with the help of travellers' reports. ${ }^{149}$ Other studies concerned the pyramids, though these are presented only from the perspective of classical Greece and Athanasius Kircher, ${ }^{150}$ and the Muslim pilgrimage to Mecca, the course and context of which Celsius was largely able to draw from the sources collected by Pococke and Hottinger. ${ }^{151}$ Parallels to Arabic literature and its rich use of metaphors are found, for Celsius, both in the riddling sayings of Scripture, especially the books of the Prophets, which could all, he believed, be traced back to the tradition of the Egyptian hieroglyphics, ${ }^{152}$ and also in the 'Golden Verses' of Pythagoras, for which Celsius considered a basis in the ancient Orient plausible. Divine perfection needed to be transmitted via tropes and images in order

144 G. Peringer - N. Sundberg (resp.), De Templo Herculis Gaditano exercitatio academica, Uppsala, 1695, passim.

145 G. Peringer - J.G. Lifver (resp.), De Heliolatreia sive cultu solis idolatrico disputatio philologica, Uppsala, 1684, passim. On Rudbeck and the trinity of Uppsala see there Thesis 11, pp. 22-3.

146 O. Celsius - M.M. Dahling (resp.), Exercitium academicum de Molecho, Uppsala, 1717.

147 O. Celsius - E.O. Berg (resp.), De Arabum in Hispania regno dissertatio, Uppsala, 1720.

148 O.Celsius - E. Klingt (resp.), Exercitium academicum de situ Paradisi terrestri, Uppsala, 1714, see there ch. 3, §§ 8-9, pp. 18-22.

149 O. Celsius - M. Kruse (resp.), Historia religionis in India orientali dissertation graduali leviter adumbrata, Uppsala, 1719, Sectio II, pp. 55-70.

$150 \quad$ O. Celsius - J. Åkerman (resp.), Historiola Pyramidum Aegypti, Uppsala, 1725.

151 O. Celsius - B. Piscator (resp.), De peregrinatione Muhammedanorum Meccana dissertatio, Uppsala, 1722, Sectio 2, §§ 1-18, pp. 10-37. See e.g. Hottinger, Historia orientalis, Liber I, ch. 7, pp. 151-62; and Pococke, Specimen Historiae Arabum, Notae, pp. 115-17. A further source was the recently published volume of A. Reland, De religione Mohammedica libri duo, Utrecht, 1705, see there Liber I, pp. 3-123.

152 Olaus C. - C.J. Mendes (resp.), Hiddot ha-qedushot seu Aenigmata sacra dissertatione philologica explicata, Uppsala, 1724, Sectio 2, ch. 2, § 2, pp. 44-5, Sectio 3, § 2, pp. 78-9. 
to bring it closer to ordinary people. ${ }^{153}$ For Celsius, there were comparable Egyptian roots also for the astral cult that was linked to the obscure 'queen of heaven', the regina coelestis, against whose worship the prophet Jeremiah had explicitly warned. ${ }^{154}$ The main focus of Celsius's engagement with Arabic came to be biblical botany. During a study trip, as Celsius himself records, he received from Golius the Arabic manuscript of a work on plant lore written by an author who had commented on Dioscorides in the tenth century, Abul Fadli ben Ahmed from Shiraz, today identified with Ibn Alkotbi. ${ }^{155}$ Celsius realized the value of the Arabic taxonomy of plants and the immense continuity of plant terminology within the Semitic languages, and he believed that it held the key to several opaque biblical plant names. A series of monographic works followed: beginning with the biblical chedeq, which Celsius is able to identify as the aubergine, ${ }^{156}$ he identifies various plants in Scripture with plants that were still common in the Orient. Celsius's extensive researches led in 1748 to the large, two-volume Hierobotanicon, which remained an influential reference work on the realia of biblical botany into the nineteenth century, and which managed to identify almost every plant in Scripture, from the famous dodaim to the palm tamar. ${ }^{157}$ In this way it provided the period's most important supplement to the Hierozoikon of Bochart.

\section{Arabic Studies Following Gustaf Peringer Lillieblad}

How was Peringer and Celsius's programme for a Scandinavian project of Arabic studies received at the Swedish universities beyond its two founding figures? The diplomat and traveller Johan Gabriel Sparwenfeld (1655-1727)

\footnotetext{
153 O. Celsius - L. Ferner (resp.), Aurea Pythagorae carmina, Uppsala, 1705, no. 48, § 2, pp. 149-53.

154 O. Celsius - Petrus Apfelbaum (resp.), Dissertatio philologica de regina coeli, Uppsala, 1727, §§ 4-7, pp. 11-24. See Jeremiah 44:16-17.

155 O. Celsius, Hierobotanicon sive de plantis Sacrae Scripturae dissertationes breves, 2 vols, Amsterdam, 1748, Praefatio (without pagination).

156 O. Celsius - S. Gestrinus (resp.), Botanici sacri exercitatio prima de Hedeq (Prov. XV et Mich. VII) ex Arabum scriptis pro modo ingenii illustratur, Uppsala, 1702, ch. 2, pp. 16-29; and e.g. id., De sacra herba Etzov disquisitio brevis, in Acta literaria et scientiarum Sueciae, 3, 1734, pp. 1-45; and id., 'Commentiuncula, quae ostenditur Ebr. Erez, esse Arabum Ers', in Acta literaria et scientiarum Sueciae, 3, 1733, pp. 50-78; id., 'Quaeritur an 'Oren Esai. XLIII. 14 sit 'Aran arbor arabica, spinosa, baccifera, Abilfadli, Materiae medicae scriptoris apud Arabes clarissimi', in Acta literaria et scientiarum Sueciae, 3, 1732, pp. 101-9. Celsius, Hierobotanicon, on the dodaim vol. 1, pp. 1-24, on the palma vol. 2, pp. 444-579.
} 
gave a large collection of Arabic manuscripts to the University Library of Uppsala. ${ }^{158}$ It is striking that the scholars directly influenced by Peringer nevertheless showed hardly any interest in treating Arabic themes in themselves: despite the large number of works produced by Palmrooth, Carolus Schulten, Boberg and Benzelius, not a single such topic is treated among them. ${ }^{159}$ The only study on the history of philosophy is a disputation by the Uppsala theologian Johannes Steuch, who like Peringer had studied with Wagenseil in Altdorf and had devoted himself to the study of Arabic logic, taking his cue from Pococke, Graevius and Hottinger. ${ }^{160}$ Almost continuously throughout Steuch's surveys he reports the theses presented in the Historia, explicitly basing his findings on Peringer and Celsius: the Greek sages had studied in the Orient and Job was the archetype of the Arab sage; ${ }^{161}$ with the coming of the Prophet, Arab life had been hit by a massive collapse in its civilisation, ${ }^{162}$ which was first restored by the Abbasid caliphs. ${ }^{163}$

We must wait two decades, until the second generation of Swedish Orientalists, before we hear a stronger echo of Peringer's efforts. A first type of disputation that we encounter is committed to the credo of treating Arabic as an exegetical language, the status of which is raised by its closeness to the primordial Hebrew language. Many of these works were produced in Turku in Finland, as Klaus Karttunen has recently shown. ${ }^{164}$ Carl Aurivillius was perhaps the most productive Orientalist and Old Testament scholar of his era in Sweden, and had studied under Schultens in Leiden; his works were deemed worthy of re-publication by Michaelis. ${ }^{165}$ Aurivillius celebrated the utility of Arabic for biblical exegesis in one of his own works in 1747, the argument of

158 J.G. Sparwenfeld, Catalogus Centuriae librorum rarissimorum manuscriptorum et partim impressorum, Uppsala, 1706, see there e.g. for the manuscripts of Ibn al-Wardī and al-Ḥusayn al-Ṭughrā'ī, no. 18, p. 31, and no. 34, p. 43. A similar collection Sparwenfeld gave to the Royal Library in Stockholm, see id., Ecloga sive catalogus librorum tum manuscriptorum impressorum, Hispanici praesertim Idiomati, quibus Regiam Bibliothecam Stockholmensem adauxit, Stockholm, 1706. Peringer wrote the preface of the catalogue.

159 A contemporary 18th century survey of Swedish Oriental studies is given by E.L. Hydrén - J.G. Humble (resp.), Specimen historico-literarium de fatis litteraturae orientalis in Suecia, Uppsala, 1755 , there e.g. on Peringer pp. $26-7$, on Norrelius p. 36.

160 J. Steuchus - C.D. Solander, Disputatio gradualis Historiam logicae Arabum exhibens, Uppsala, 1721, § 2, pp. 3-9.

161 Ibid., § 1, pp. 1-3, § 5, pp. 12-22.

162 Ibid., § 6, pp. 22-25.

163 Ibid., § 7, pp. $25^{-27}$.

164 Karttunen, Moseeksen kirjoista kungfutselaisuuden klassikoihin, pp. 111-17.

165 C. Aurivillius, Dissertationes ad sacras litteras et philologiam orientalem pertinentes, cum praefatione Joannis Davidis Michaelis, Leipzig, 1790. On Carolus Aurivillius see Anner- 
which closely follows that of Peringer's Historia, being based, like its model, primarily on Hottinger and Pococke: Arabic is directly derived from the lingua adamica and for that reason is of special dignity. ${ }^{166}$ Aurivillius gave examples of this usefulness again later in a study devoted to the Decalogue, the lexicology of which he was able to illuminate word by word from Arabic. ${ }^{167}$ Another work by Aurivillius on Arabic is based directly on Celsius, namely a Latin translation of the botanical encyclopedia of Ibn al-Wardī, an author of the fourteenth century. ${ }^{168}$

Other scholars around the shores of the Baltic also picked up the theme of the privileged position of Arabic and celebrated it in the spirit of Peringer in apologias of their own. A direct student of Aurivillius, Carl Abraham Clewberg, who was an amazingly productive Hebrew scholar and theologian, underlines the privileged position of Arabic in his Specimen de usu linguae Arabicae, ${ }^{169}$ delivered in 1757 at the University of Turku, directly citing Schultens, but stresses even more strongly than his predecessors the primeval status of Arabic. ${ }^{170}$ He demonstrates its closeness to the primordial Hebrew language with a whole series of examples. ${ }^{171}$ Finnish scholars like Eric Cajanus (as Clewberg knew), whose disputation was supervised by the theologian Daniel Lundius, or Daniel Weman had at the same time attempted to show that the Finnish and Estonian languages must also have arisen directly out of Hebrew, ${ }^{172}$

stedt, Uppsala Universitets Historia. Tredje Delen, vol. 2, pp. 371-2, pp. 396-400; Lindroth, Svensk Lärdomshistoria, vol. 3, pp. 589-92.

166 C. Aurivillius - E. Hallgren (resp.), Disputatio philologica de usu dialecti Arabicae in indaganda vocum Ebraicarum significatione propria et orginaria, in Dissertationes ad sacras litteras, no. 1, pp. 1-40 (first Uppsala, 1747), §§ 2-6, pp. 3-11.

167 C. Aurivillius - A. Thorberg (resp.), Decalogus Hebraicus ex Arabica dialecto illustratus, in Dissertationes ad sacras litteras, no. 26 (first Uppsala, 1782), pp. 560-73.

168 C. Aurivillius - E. Axelsson (resp.), Particula ex opere cosmographico Ibn Alvardi latine versa et notis illustrata, in Dissertationes ad sacras litteras, no. 2 (first Uppsala, 1752), pp. 41-73.

169 On Clewberg in general see Heikel, Filologins studium, pp. 188-92. A detailed summary of this disputation now is given by T. Harviainen and K. Karttunen, 'The Outset of Arabic Studies in Finland with Notes on Finnish: Carolus Clewberg and Michael Avellan', in Travelling through time. Essays in honour of Kaj Öhrnberg, eds S. Akar, J. Hämeen-Anttila and I. Nokso-Koivisto, Helsinki, 2013, pp. 427-56.

170 C.A. Clewberg - M. Avellan (resp.), Specimen philologicum usum Arabicae in perficiendo lexico hebraeo sistens, Turku, 1747 , § 1, pp. 1-3.

$171 \quad$ Ibid., $\S \S 5-8$, pp. 9-18.

172 D. Lund - E. Cajanus (resp.), De linguarum hebraicae et fennicae convenientia, Turku, 1697, Membrum II, pp. 7-13, and later C.G. Weman - B. Ignatius (resp.), De convenientia linguarum Hebraeae et Fennicae, Turku, 1767, there e.g. § 4, pp. 12-14, 
indeed, among the European languages they were perhaps the ones most closely related to it. ${ }^{173}$ The final section of Clewberg's study is therefore devoted to the attempt to show proximity between Arabic and Finnish through long comparisons of vocabulary. ${ }^{174} \mathrm{~A}$ few years later Clewberg's colleague in Turku, Lars Lefrén, ${ }^{175}$ was able to show how a passage from Genesis can only be explained with reference to Arabic. ${ }^{176}$ To support his exegesis, Lefrén does not shy away from noting onomatopoetic correspondences in Old Swedish. ${ }^{177}$ These kinds of parallelisms were only possible because the idea of a primordial language as a whole was widely held to be beyond challenge.

Michael Avellan, who had served as respondent in Clewberg's Specimen, ${ }^{178}$ followed this up in 1761 with a study, written together with his brother, which once again restated his theses about the exceptional position of Arabic. For the Finn Avellan, too, the supporting authorities are, in addition to Hottinger, Erpenius and Schultens, primarily Peringer and Celsius, whose assessment of the wisdom of the ancient Arabs Avellan wholly supports. ${ }^{179}$ Disputations of identical content were delivered in Lund in 1784 by Henrik Ståhl, 180 in Uppsala in 1791 by Elias Hedendahl, ${ }^{181}$ and in Turku the same year by Pehr Malmström, another student of Aurivillius. Malmström provided a whole catalogue of arguments that can be adduced in favour of the study of Arabic: not just the almost

173 On the supposed relationship between Finnish and Hebrew see T. Harviainen, 'Ragaz ja rakas. Kai on suomikin heprean sukua?', in Kirjoja ja muita ystäviä. Onnittelukirja Kaari Utriolle ja Kai Linnilälle, ed. M. Paulaharju, Hämeenlinna, 2002, pp. 69-74; and id., 'The Story of Supposed Hebrew-Finnish Affinity a Chapter in the History of Comparative Linguistics', in Inquiries into Words. Constraints and Contexts: Festschrift in the Honour of Kimmo Koskenniemi on his 6oth Birthday, ed. A. Arpe, Saarijärvi, 2005, pp. 289-306, there e.g. on Lundius and Cajanus pp. 294-7, and with many details Roling, 'Von der Magie zur Poesie', pp. 236-44.

174 Clewberg - Avellan, Specimen philologicum usum Arabicae, § 9, pp. 18-20. See also Harviainen and Karttunen, 'The Outset of Arabic Studies', pp. 445-50.

175 On Lefrén see Heikel, Filologins Studium, pp. 192-93, Råberg, Teologins historia, pp. 12433 .

176 L. Lefrén - I. Arenander (resp.), Dissertatio gradualis de gemina versione arabica exclamationis Adami, Gen. II, 23, Turku, 1714, §§ 1-2, pp. 3-5, § 4, pp. 6-8.

177 Ibid., § 9, pp. 13-14.

178 On Avellan see Heikel, Filologins Studium, p. 211, Råberg, Teologins historia, pp. 120-21.

179 M. Avellan - C. Avellan (resp.), Dissertatio historico-philologica de caussis puritatis ac floris perennis linguae Arabicae, Turku, 1761, passim, on Peringer esp. § 4, pp. 8-9.

180 H. G Ståhl - T. Linnell (resp.), Dissertatio academica in eo occupata, ut rationes nonnullas, quae linguam Arabicam cultoribus perdiscendam suadeant, Lund, 1784, passim.

181 E. Hedendahl - C.E. Hultin (resp.), Dissertatio philologica de necessitate et utilitate linguae Arabicae cum reliquis dialectis theologo, Uppsala, 1791, passim. 
divine origin of the idiom, its immense duratio and the archaic knowledge above all astronomy, mathematics and medicine - that it transmits, and the utility of Arabic for scriptural exegesis and the study of philosophy, ${ }^{182}$ but also the superiority of Arabic poetry, proclaimed by William Jones in this period. ${ }^{183}$

A second type of Arabic study in the Swedish empire picked up themes that had been established by the major figures of Oriental studies cited already by Peringer, viz. Pococke, Fabricius Dantiscanus and Hottinger. Peringer and Celsius had not made much of the Qur'an, which they had characterized as the beginning of the decadence of Arabic. Eric Fahlenius, a doctoral student of Johannes Esberg who would later enjoy a career as professor in Pernau, ${ }^{184}$ felt called upon to demonstrate in detail the falsification of the Qur'an by the deceitful Prophet. ${ }^{185}$ With this goal, Fahlenius believed that he could derive numerous suras from Jewish sources, which he drew in part from rabbinic tradition and in part from kabbalistic works like the Zohar, which he himself had helped to make available in Sweden. ${ }^{186}$ Fahlenius was followed in his harsh judgment on the authenticity of the Qur'an by Jonas Sidrén in his Historiola literaria Corani, ${ }^{187}$ which he followed with a list of editions existing to date. ${ }^{188}$ The first Latin translation of some Qur'an passages, namely the first and second suras, which were for the most part collated from the editions of Maracci and Hinckelmann, was produced only in 1793 by Pehr Malmström. ${ }^{189}$ In addi-

182 P, Malmström - G, Krogus (resp.), De vario usu litteraturae orientalis dissertatio academica, Turkum 1791, §§ 1-7, pp. 3-24.

183 Ibid., § 8, pp. 24-26. On the same matter A. Kahl - P.W. Bjerken (resp.) - I. Thomberg (resp.), Commentatio academica de connexione linguarum Arabicae et Hebreae sacri codicis interpreti necessaria, Lund, 1821, there esp. § 2, pp. 7-13.

184 On E. Fahlenius see Schoeps, Philosemitismus im Barock, pp. 144-45, p. 153; von Rauch, Die Universität Dorpat, pp. 350-51; and H. Piirimäe, Ülikoolilinn Pärnu, p. 85, p. 115.

185 On Fahlenius's refutation of the Qur'an see in detail B. Roling, 'Humphrey Prideaux, Eric Fahlenius, Adrian Reland, Jacob Ehrharth und die Ehre des Propheten. Koranpolemik im Barock', in Die Wahrnehmung des Islams in Reformation und Aufklärung, eds D. Klein and B. Platow, Munich, 2008, pp. 61-76, (69-70).

186 J. Esberg - E. Fahlenius (resp.), Historiola Al-Korani et fraudum Muhammedis, Uppsala, 1699, see there e.g. ch. 2, pp. 15-19, pp. 23-4, pp. 25-6, pp. 28-9. Very close to Fahlenius was P. Holm, Muhammad ar-rasul al-kadib sive Theologiae Muhammedanae brevis consideratio, Jena, 1670, who made extensive use of Elmacinus, too. Holm was a Swedish theologian, who studied in Jena, but later returned to Lund. See there on the Trinity in the Qur'an e.g. Pars II, ch. 3, fols $\mathrm{G}_{2}^{\mathrm{v}}-\mathrm{G}_{4}$.

187 J. Sidrén - A. Stolpe (resp.), Historiola litteraria Corani, Uppsala, 1792, § 1, pp. 3-4.

188 Ibid., $\S \S 4-5$, pp. 5-9.

189 P. Malmström - J.H. Fallenborg (resp.) - J.H. Avellan (resp.), Specimen AlCorani arabice et latine, 2 vols, Turku, 1793-94. On Malmströms person see Heikel, Filologins Studium, pp. 245-51. 
tion to these works, which breathe the spirit of the anti-Qur'anic polemics of the likes of Humphrey Prideaux, ${ }^{190}$ in the mid-eighteenth century there are also treatises and disputations that offer a new commentary on the 'Carmen Tograi', a didactic poem by al-Ṭughrāī that Pococke had published, ${ }^{191}$ or other works by this author, who had become known through the publications of the English scholars. ${ }^{192}$ The Uppsala theologian Johan Adam Tingstadius (17481827), who became one of the important Swedish Bible translators, picks up the same text to look for parallels to the lexicography of Scripture. ${ }^{193}$ Following William Jones's Oriental Poetry, but also Herder's Vom Geist der Ebräischen Poesie, Eric Myrberg in 1798 elucidated the parashot of Isaiah and parts of the Psalms with the help of Hafiz and other Eastern poets, aiming to explain their tropology. ${ }^{194}$ In Lund, finally, Anders Hylander (1750-1830) continued the work of Aurivillius on the manuscript of Ibn al-Wardī. ${ }^{195}$

190 H. Prideaux, The Old and New Testament connected, in the history of the Jews and neigbouring nations: from the descension of the Kingdoms of Israel and Judah, to the time of Christ, London, 1716. On this widespread pamphlet against the prophet, which in the year 1800 also was translated into Swedish, see Toomer, Eastern Wisedome, pp. 289-93; Roling, 'Humphrey Prideaux, Eric Fahlenius', pp. 62-8; and P.M. Holt, 'The Treatment of Arab History by Prideaux, Ockley and Sale', in Historians of the Middle East, eds B. Lewis and P.M. Holt, London, 1963, pp. 290-302, here pp. 290-94.

191 G. Gadolin - D. Backman (resp.), Lamicum carmen Abu-Ismaelis Tograi latine explicatum, Turku, 1790, passim. On Gustaf Gadolin see Råberg, Teologins historia, pp. 196-200; and Rein, Filosofins studium, p. 290.

192 P.J. Appelberg - L.A. Palm (resp.), Specimen academicum exhibens historiam Chamazujae secondi in Aegypto Sultani, arabice cum versione latina, Lund, 1785 .

193 J.A. Tingstadius - B. Hesselgren (resp.), Dictiones arabicae ex carmine Tograi Hebraismum biblicum illustrans, Uppsala, 1794, there e.g. on Hafiz, using William Jones p. 11. Extensive use of Arabic is made by Tingstadius also in J.A. Tingstadius, Specimen supplementorum ad Lexica Hebraica, 8 vols, Uppsala, 1791-1803. Already when he startet his career in Greifswald, Tingstadius proclaimed the purity of the Arabic language and its close relationship with the primordial language, see J.A. Tingstadius - J. Clarström (resp.), Mediationes historico-philologicae de ortu et cognatione linguarum orientalium, Greifswald, 1768, $\S$ 9, pp. 16-19. Later Tingstadius repeated these ideas many times, see also for example. J.A. Tingstadius, Strödde anmärkningar öfver Hebraiska och Arabisca dialecterna, af bifogas vid den grammatica, man i dessa språk helst vill följam till språkälskares tjenst, Uppsala, 1820, passim, and his programmatic speech, held in Uppsala, J.A. Tingstadius, Inträdes-tal om österlandska poësiens egenskaper, Uppsala, 1786, passim.

194 E. Myrberg - E. Kjersen (resp.), Monumenta quaedam poëseos Hebraeae et Arabicae, Uppsala, 1798, passim. On a similiar matter see also S.F. Lidman - I.H. Kinnander (resp.), Dissertatio de antiquae poëseos Arabicae genio, Uppsala, 1807, passim.

195 A. Hylander, Specimen operis cosmographici Ibn el-Wardi ex lingua arabica in latinam conversum, 38 vols, Lund, 1784-1809, see there for example the description of Rome Pars 16, 


\section{Arabic Studies in the Twilight of the National Ideology: Jonas Hallenberg and Matthias Norberg}

Peringer's attempts to give the solar cult at Uppsala an Oriental prehistory, and the consequent insistence on a divinely bestowed primordial language from which both Old Norse and Arabic could be derived with equal assurance, in themselves make it clear that Swedish Orientalism had a national character for which Peringer himself is partly responsible.

For philologically inspired gothicism it was Olaus Rudbeck the Younger, son of Olaus Rudbeck the Elder, who, at the start of the eighteenth century, had taken the national-mythological model of linguistics to its extreme. ${ }^{196}$ Engagement with other Semitic languages could not remain untouched by this project. After an expedition to Lapland at the behest of the King, ${ }^{197}$ Olaus Rudbeck the Younger, in 1695 - almost the same time as the appearance of the Historia - had reached the conclusion that the Sami language must reflect Hebrew in the purest fashion, and this for one simple reason: the lost tribes of Israel had, Rudbeck believed, found a new home in Lapland after their expulsion from the Holy Land, in the form of the Sami. ${ }^{198}$ Their rites and all

pp. 134-5. His son S. Hylander, Index Geographicus in caput primum operis cosmographici Ibn el-Wardi, 5 vols, Lund, 1823 , added an extensive index.

196 On Olaus Rudbeck the Younger and his linguistic models see J. Agrell, Studier $i$ den äldre språkjämförelsens allmänna och svenska historia fram till 1827, Uppsala, 1955, pp. 119-25; E. Hovdhaugen and F. Karlsson, The History of Linguistics in the Nordic Countries, Jyväskylä, 2000, pp. 117-19; G.J. Stipa, Finnisch-ugrische Sprachforschung von der Renaissance bis zum Neupositivismus, Helsinki, 1990, pp. 187-91; Roling, 'Erlösung', pp. 400-1; id., 'Von der Magie zur Poesie', pp. 234-6; Schoeps, Philosemitismus im Barock, pp.105-9; and already Erkki Itkonen, Suomalais-ugrilaisen kielen- ja historiantutkimuksen alalta, Helsinki, 1961, pp. 133-4. A dissertation on Rudbeck the Younger is currently going to be prepared under my supervision by Stefan Bauhaus.

197 A summary of Rudbeck's expedition is given in the preface to the facsimile of Rudbeck's notebook, see O. Rudbeck the Younger, Iter lapponicum. Skissboken från resan till Lappland 1695, 2 vols, Stockholm, 1987, vol. 2, Commentary, pp. 7-27; and in addition already T.M. Fries, 'De första naturvetenskapliga forskningsfärden i Sverige', in Nordisk Tidskrift förvetenskap, konst och industri, 1898, pp. 481-97, pp. 517-37. The majority of the volumes, which should have appeared as travel-journal were destroyed in the city fire of Uppsala in 1702. See in the only printed volume on the relationship between the Sami and the Hebrew O. Rudbeck the Younger, Nora Samolad sive Lapponia illustrata, Uppsala, 1701, e.g. Latin and Swedish pp. 51-2, pp. 74-5, for Arabic etymologies see e.g pp. 27-8.

198 On the role of the Sami in academical Swedish culture see the survey R. Pulkkinen, 'Myytiset saamelaiset', in Beaivvi Mánát. Saamelaisten juuret ja nykyaika, ed. Irja SeurujärviKari, Helsinki, 200o, pp. 41-64; and esp. S. Virkkula, Lappi kirjallisuudessa barokista 
their customs matched the life of the ancient Israelites, as Rudbeck is able to show through a whole series of special studies, ${ }^{199}$ and their language could be paralleled with Hebrew through lengthy comparisons of vocabulary. ${ }^{200}$ If the biblical Japhethites had migrated to Sweden straight after the Deluge, and the crypto-Jewish element had been reinforced by the subsequent migration to the North of the no less Biblical Sami, it must be possible to derive not only Hebrew and Arabic, but also Sami and Finnish, Old Norse and Gothic from a single basis, and they could elucidate each other's semantics. Inspired by this insight, from 1705 Rudbeck in Uppsala set about drawing up a linguistic atlas, the Thesaurus linguarum Asiae et Europae, in a total of 12 volumes, ${ }^{201}$ of which however he only managed to publish a single fascicle. ${ }^{202}$ Assuming as starting point a Semitic-Germanic-Finno-Ugric foundation, this atlas included not only most Semitic and Indoeuropean languages but also Chinese, which Rudbeck believed could be assigned to the eastern part of the former Scythian empire, and various African as well as native American languages, all seen as deriving from the primordial language. ${ }^{203}$

romantiikaan, Oulu, 2000, passim. On the treatment of the Sami in contemporary academic disputations in general see in addition B. Roling, 'Der Schamane und das Orakel von Delphi. Prophetie und Prophetiemodelle im frühneuzeitlichen Skandinavien', in Prophetie und Autorschaft. Charisma, Heilsversprechen und Gefährdung, eds Christel Meier and Martina Wagner-Egelhaaf, Berlin, 2014, pp. 277-304, (291-302).

199 O. Rudbeck the Younger, 'Epistola ad Fabianum Tornerum de Estonum, Fennonum, Lapponum origine', in Acta literaria Sueciae 2, 1727, pp. 300-306; id., 'Descriptio Cataracti in Cascawari Laponiae', in Acta literaria Sueciae, 3, 1734, pp. 46-8; and see also id., Ichthyologiae biblicae pars secunda de Borith Fullonum, Uppsala, 1722, pp. 145-6. Rudbeck wrote also a dictionary of Sami language, see O. Rudbeck the Younger, Glosarium Laponicum, UUL, MS Ihre, sig. Ihre 104.

200 O. Rudbeck the Younger, De convenientia hebraicae et lapponicae linguae, Uppsala, 1703, printed in J.C. Wolf, Bibliotheca Hebraica, Pars II, Hamburg, 1721, pp. 639-48, there the Sami-Hebrew glossary, pp. 641-8; and id., Atlantica illustrata sive illustrium, nobilium, principum atque regum insula, ubi et Prisci Hesperidum horti, Uppsala, 1733, there another glossary pp. 68-73.

201 O. Rudbeck the Younger, Lexicon linguarum Asiae et Europae harmonicum, UUL, MS Rudbeck, sig. R 1-12, 12 vols.

202 O. Rudbeck the Younger, 'Thesaurus linguarum Asiae et Europae harmonicus', in Acta literaria Sueciae, 3, 1733, pp. 90-106, an extract of the the letter A; and id., Thesaurus linguarum Asiae et Europae harmonicus, Uppsala, 1717, the glossary on the letter A, with many Arabic words pp. 9-16.

203 Rudbeck prepared a separate treatise, to demonstrate the relationship between american native tongues and the primordial Semitic-Germanic-Finno-Ugric language, see O. Rudbeck the Younger, 'Oförgripelige tankar om Amerikanska språket', in Smärre språkvetenskapliga avhandlingar, UUL, MS Rudbeck, sig. R 12b, no. 5 . 
In the following years Rudbeck the Younger attempted to make the results of this mammoth project useful also for exegesis, in the form of a series of essays and, in some cases, ambitious treatises. Various obscure passages of Scripture could, Rudbeck believed, be filled with new meaning through an amalgam of Hebrew and Arabic analogies and by comparing roots and analogous vocabulary in Old Norse, Sami and Finnish. The sign of the covenant, ot, given to Noah had been a rainbow right from the start, as could be shown by comparison with a related Sami term. ${ }^{204}$ The ominous selav, which the Vulgate had translated as coturnix, was revealed as a flying fish, ${ }^{205}$ the ramash from the ninth chapter of Genesis as a reindeer, ${ }^{206}$ and the dodaim that Rachel received from Leah, and which Celsius had preferred to identify as mandrakes, were in reality just strawberries. ${ }^{207}$ In the following years, in collaboration with Johan Kemper, who had already prefaced the report of the Lapland expedition with a dedicatory poem, ${ }^{208}$ Rudbeck also integrated kabbalistic ideas and representations into his linguistic speculation. Names like Metatron or El Shaddai became symbols of Christ and the Trinity through reference to their Old Norse roots. ${ }^{209}$ In this web of explanations supported by immense knowledge of detail and often by observations that were in fact quite correct, Arabic was continuously present and even held its ground as the most important exegetical language alongside Finnish and Old Norse. Even Bible commentaries would be written

204 O. Rudbeck the Younger, Specimen usus linguae Gothicae in eruendis atque illustrandis obscurissimis quibusvis Sacrae Scripturae locis, Uppsala, 1717, on the role of Arabic pp. 8-9, Chinese pp. 60-76, the Sami as Lost Tribe pp. 81-84, the rainbow pp. 202-03.

205 O. Rudbeck the Younger, Ichthyologiae biblicae pars prima de ave Selav cuius mentio fit Num. XI: 31, Uppsala, 1705, pp. 30-33.

206 O. Rudbeck the Younger, 'Cogitationes de voce Ramash Gen IX', vol. 3, in Acta literaria Sueciae, 2, 1728, pp. 416-22, pp. 426-35. The serpent of the Paradise, nachash, could be derivated, last but not least from the germanic root 'Naschen', see O. Rudbeck the Younger, 'Om Nachash eller om ormen i paradiset', in Smärre språkvetenskapliga avhandlingar, UUL, Ms Rudbeck, sig. R 12b, no. 3, esp. § 7; the ceder, eretz, from the root 'rise', see Olaus Rudbeck the Younger, 'Om Libanons ceder', in Smärre språkvetenskapliga avhandlingar, UUL, MS Rudbeck, sig. R 12b, no. 4, esp. § 3 .

207 O. Rudbeck the Younger, Dudaim Rubenis, quos neutiquam Mandragorae fructus fuisse, Uppsala, 1733, pp. $15^{-16 .}$

208 Rudbeck the Younger, Nora Samolad, preface (without pagination).

209 O. Rudbeck the Younger, 'Cogitationes de nominibus divinis Schadi et Metatron', in Acta literaria Sueciae, 2, 1729, pp.539-47, pp. 562-73. On the Tetragrammaton see also id., Ichthyologiae biblicae pars prima, pp. 14-28. 
in the spirit of Rudbeck the Younger, which could present for every word of Genesis one chain of Arabic-Hebrew roots and another one of Old Norse. ${ }^{210}$

The extent to which Arabic studies in Sweden, following Peringer, were under the influence of similar universalistic constructions, and were perhaps inspired as much as they were misled by them, is made clear, finally, by the example of the two most prominent Orientalists of the late eighteenth century, Jonas Hallenberg and Matthias Norberg. In both cases, their contribution to Oriental studies is not in dispute. Both show at the same time that a baroque conception of knowledge and the advancing specialisation of Oriental studies into individual disciplines did not necessarily conflict even in the early nineteenth century.

Jonas Hallenberg had begun his career as a historian; ${ }^{211}$ his most important works include a history of the regency of Gustavus Adolphus and a Nya allmäna historien, ${ }^{212}$ which was later to be followed by a detailed commentary on Sven Lagerbring's Swedish History. ${ }^{213}$ This and other studies earned him the office of Swedish Royal Antiquary. In addition to his activity as a historian, Hallenberg had a wide-ranging interest in the ancient Norse world and the archaeology of Sweden, which led to a series of publications on recent discoveries. ${ }^{214}$ Hallenberg's enthusiasm for numismatics was crowned by the office of supervisor of the Royal Coin Cabinet, the holdings of which he catalogued in detail. ${ }^{215}$ His special interest was the Kufic coins, which were generously

210 As attempts to combine old Norse language and Bible commentary see e.g. D. Annerstedt - J.O. Johannson (resp.), Parallelismus inter linguam Hebraicam et Sviogothicam, Pars prima, Uppsala, 1764, on Genisis 1:1; and D Annerstedt - J Åberg (resp.), Parallelismus inter linguam Hebraicam et Sviogothicam, Continuatio, Uppsala, 1768, on Genesis 1:2; or even C. Aurivillius - A. Svedelius (resp.), Dissertatio gradualis de Cosmogonia mythologica, Uppsala, 1761, there esp. § 2, pp. 7-8, § 3, pp. 9-12.

211 On the life and work of Jonas Hallenberg see the surveys of B.E. Hildebrand, Minnesteckning öfver Jonas Hallenberg, Stockholm, 1880; N. Ahnlund, Jonas Hallenberg. Minnesteckning, Stockholm, 1957; Agrell, Studier i den äldre språkjämförelsens allmänna och svenska historia, pp. 168-72; and Lindroth, Svensk Lärdomshistoria, vol. 4, pp. 282-8, pp. 305-10.

212 J. Hallenberg, Nya allmaenna historien ifrån boerjan af sextonde århundradet, 3 vols, Stockholm, $1783^{-88 .}$

213 J. Hallenberg, Öfver första delen af Sven Lagerbrings's Svea Rikes Historia: Anmerkningar, 2 vols, Stockholm, 1819-22.

214 On archaeological strata see e.g. J. Hallenberg, Quatuor monumenta aenea e terra in Suecia eruta, Stockholm, 1802; id., Berättelse om ett i Motala ström träfffadt fynd, Stockholm, 1818; id., Berättelse om ett forntids romerskt metallkärl, funnet $i$ Westmanland år 1818; id., Berättelse om twänne fynd, det ena träffadt på Öland, år 1815, det andra i Bohuslan, år 1816, Stockholm, 1821.

215 J. Hallenberg, Berättelse om Svenska Kongliga Mynt-Cabinettet, Stockholm, 1804. 
represented there and which Aurivillius and Clewberg had already studied and commented upon. ${ }^{216}$ Many of these coins were from Viking hoards found in Sweden itself. Hallenberg's friend, the great Orientalist from Bützow, Olof Tychsen, had only a few years previously written the great standard work on Arabic numismatics. ${ }^{217}$

Right from the start, Hallenberg had seen himself also as a theologian and Orientalist. Already in 1800 he had presented a monumental, over 1500-page commentary on the Book of Revelation, the chapters of which Hallenberg had exhaustively elucidated with rabbinic parallels. ${ }^{218}$ In a similar way to Rudbeck the Younger, the Swedish scholar worked for years on a comparative atlas of languages which, in its ambition, rivalled Rudbeck's project and which, like its counterpart, never got into print. ${ }^{219}$ Further monumental studies, including a 'History of Ancient Persia', also remained in manuscript. ${ }^{220}$ Hallenberg, too, had no doubt that all languages shared a substrate and that it must be possible to demonstrate their relationship to each other. Through their age and affiliation to Hebrew, the Semitic languages, and foremost among them Arabic, must take first place in this system of relationships; alongside them, as Hallenberg like Rudbeck believed, stood the linguistic remains of the Old Norse civilisation. Each language group could therefore explain the other. In a similar way to

216 J. Hallenberg, Collectio nummorum Cuficorum, quos aere expressos, addita eorum interpretatione, subiunctoque alphabeto Cufico, Stockholm, 180o; id., Numismata orientialia aere expressa brevique explanatione enodata, 2 vols, Uppsala, 1822. See earlier C.A. Clewberg - M. Lundbeck (resp.), Dissertatio academica de nummis arabicis in patria repertis, Turku 1755, passim; and Carl Aurivillius, 'De nummis Arabicis in Sviogothia refertis disquisitio', in Nova Acta Regiae Societatis Scientiarum Upsalensis, 2, 1775, pp. 79-107.

217 O.G. Tychsen, Introductio in rem numariam Muhammedanorum, 4 vols (cum additionibus), Rostock, 1794-97; and id., De numis Hebraicis diatribe, qua simul ad nuperas ill. Franc. Perezii Bayerii obiectiones respondetur, Rostock, 1791.

218 J. Hallenberg, Historiska anmärkningar öfver uppenbarelse boken, 3 vols, Stockholm, 180o; and see in additionally J. Hallenberg, Dogmatis de resurrectione corporum mortuorum origo, Stockholm, 1798. The manuscript collection of Hallenberg includes a further similar work e.g UUL, MS Hallenberg, sig. T 12; and a commentary on the Psalms e.g UUL, MS Hallenberg, sig. T 155-156, 2 vols.

219 J. Hallenberg,Jämförande ordbok, uUL, MS Hallenberg, sig. R 31-62, 32 vols. See also Agrell, Studier i den äldre språkjämförelsens allmänna och svenska historia, p. 171.

220 J. Hallenberg, De rebus regum Persiae ante introductam religionem Muhammedicam sive Historia Persiae antiquae e Persico, UUL, Ms Hallenberg, sig. H 348-350, 3 vols. In fact, this manuscript is a translation of Ahmad al-Ghaffārì's Epitome of the Ancient History of Persia, ed. William Ouseley, London, 1799, but with many notes, added by Hallenberg. In addition, Hallenberg wrote Ad historiam regni Persici adversaria, UUL, MS Hallenberg, sig. H 351 . 
Rudbeck the Younger, for Hallenberg, too, the Kabbala was a universally present primeval tradition that linked the Semitic world with the remains of Old Norse culture at another, admittedly hidden, level. ${ }^{221}$ The Trinitarian figures of the sefirot system, which Norrelius had identified as the central Christian element of the Kabbala, had a significance for both cultures. In 1805, with Tychsen's help, a 'Secret Doctrine of the Orientals' appeared, in which Hallenberg not only provided an introduction into the mysticism of the sefirot, but also put together a panorama out of a patchwork of neoplatonic elements taken mostly from Proclus, in which a triad of light, time and number was matched to the trinity of Uppsala, Odin, Thor and Freya, and which corresponded to the god of light, Apollo, enthroned on a tripod. ${ }^{222}$ Hallenberg further made extensive use of the first introductions to Indian mythology, Thomas Maurice's Indian Antiquities, ${ }^{223}$ Paulinus de Bartholomae's Systema brahmanicum, ${ }^{224}$ but also of the Alphabetum tibetanum of Antonio Giorgi, ${ }^{225}$ today hardly remembered at all, in order to match the first triad of sefirot to the Indian trimurti of Brahma, Vishnu and Shiva and other elements of Indian reli-

221 On the role of Kabbalah in general see already Hallenberg, Historiska anmärkningar, vol. 1, pp. 14-28.

222 J. Hallenberg (anonym), Die Geheime Lehre der alten Orientaler und Juden, zur inneren und höheren Bibelerklärung, aus Rabinern und der ganzen alten Literatur, von einem grossen Philologen des Auslandes, Rostock, 1805, see there esp. pp. 42-53. The original Swedish manuscript was later published as J. Hallenberg, Ljus öfver bibeln! eller, De gamle Orientalers och Judars hemliga lära för skriftens inire och rätta mening, Stockholm, 1875.

223 T. Maurice, Indian Antiquities, or dissertations relative to the antient geographical divisions, the pure system of primeval theology, the grand code of civil laws, the original form of government, the widely-extended commerce and the various and profound literature of Hindostan, 7 vols, London, 1794-1806; and see esp. id., A dissertation on the oriental trinities, extracted from the fourth and fifth volumes of Indian Antiquites, London, 1800.

224 P. a Sancto Bartholomaeo, Systema brahmanicum liturgicum, mythologicum, civile ex monumentis indicis Musaei Borgiani Velitri dissertationibus historico-criticis, Rome, 1791; and in addition esp. id., De antiquitate et affinitate linguae Zendicae, Samscrdamicae et Germanicae dissertatio, Padova, 1798. De Bartholomae's writings had received more attention in Sweden than the contemporary studies of William Jones. There even existed a Swedish translation of his Travel Journal, the Viagio alle Indie Orientale, prepared by the Linnean Samuel Oedmann, see Donald Campbells Land-Resa til Indien och Fra Paolinos da San Bartholoeo Resor uti Indien, Stockholm, 1801.

225 A.A. Giorgi, Alphabetum Tibetanum missionum apostolicarum commodo editum, Rome, 1762. For a useful survey of this important work, the first written on Tibet at all, see now C. Bellini, Svelare il paese dell nevi. L'Alphabetum tibetanum di Agostino Antonio Giorgi, Villa Verucchio, 2011, pp. 49-80. 
gion. ${ }^{226}$ This primordial triad was extended, in Hallenberg's postulated universal religion, by two further elements: the cult of the celestial heptad, which could also be traced as a blueprint from the Egyptians into the branches of Indoeuropean mythologies; and by the assumption of a God incarnate, a mies, manusya or enosh as had been found by Norrelius in the lower sefirot, and which could equally well be found in all cultures. ${ }^{227}$

The Arab world, too, had to be accommodated in the matrix of a philosophia perennis that oscillated between Kabbala, the Edda's account of the gods, and the assumption of a universal language. Already in 1796 Hallenberg had been prompted by an eighth-century Kufic coin on which, with sura 112, the oneness of God was three times repeated, to distill out of Old Norse mythology and the Qur'an an amalgam of the lexical fields Gud, ahad, choda, Odin and agathos, the wide-ranging branches of which, Hallenberg believed, could be traced back to the ancient Egyptian cult of the sun and which also had to find room for a battery of Finno-Ugric languages. ${ }^{228}$ All cultures had always been familiar with a perfect, ultimate, luminous, highest Good that embraced trinity and unity equally; Islam had preserved an especially pure recollection of this ultimate primeval basis of all religions. Hallenberg's speculative enthusiasm, which was supported by extensive materials and daunting linguistic knowledge, reached its climax in a text from 1816, the Disquisitio de nominibus in lingua Sviogothica lucis et visionis, which extended the approach of the previous work by universalising it even further; now, over almost 1200 pages, the canon of cited languages was increased several times over. ${ }^{229}$ Hallenberg no longer believed in a lingua adamica, as Stiernhielm and Rudbeck had taught, but rather in a primordial language that could be grasped onomatopoeically, in which the semantic field of sun and light could be articulated in the first sound patterns. ${ }^{230}$ Beginning with the Semitic languages, above all Hebrew and Arabic, sounds could be found in all languages that had captured the flickering

226 Hallenberg, Die Geheime Lehre der alten Orientaler, pp. 53-6. For very similar ideas see Hallenberg's contemporary N.H. Sjöborg, Samlingar för Nordens fornälskare, innehållande inskrifter, figurer, ruiner, verktyg, Stockholm, 1822-30, vol. 2, pp. 80-91, pp. 109-12.

227 Hallenberg, Die Geheime Lehre, pp. 58-66, pp. 80-99.

228 J. Hallenberg, Ex occasione nummi cufici de nominis Dei Gud, in Suio-Gothica cognatisque linguis origine, Stockholm, 1796, ch. 1-6, pp. 8-79, passim.

229 On the 'Disquisitio' of Hallenberg and the ambigious reactions it received together with the treatise 'Ex occasione', see Hildebrand, Minnesteckning, pp. 16-18; and Ahnlund, Jonas Hallenberg, pp. 226-39.

230 J. Hallenberg, Disquisitio de nominibus in lingua Suiogothica Lucis et Visus cultusque solaris in eadem lingua vestigiis, 2 vols, Stockholm, 1816, vol. 1, pp. 1-7, and pp. 180-286. It is almost impossible to sum up the treatise. 
of light and the hissing of fire. ${ }^{231}$ Repeatedly Hallenberg reconstructed across cultures a lexical field from terms for 'seeing', 'sun', 'light' and 'god', ${ }^{232}$ with majestic filiations and meandering chains of derivation that in his work finally reach an end in an analysis of the primordial Yule festival, the winter solstice, in Uppsala. Rudbeck had once again found an audience. ${ }^{233}$

Matthias Norberg (1747-1826), who had studied under Aurivillius but became professor in Lund, was far more distinguished as an Orientalist than even Hallenberg. ${ }^{234}$ Among the almost 180 studies that he produced, ${ }^{235}$ Norberg had proved himself primarily as an expert in Syriac, ${ }^{236}$ but had also presented studies on Arabic medicine, ${ }^{237}$ astronomy ${ }^{238}$ and geography, ${ }^{239}$ on the Ottoman empire and on the Qur'an; ${ }^{240}$ at the same time, he had in several works endeavoured to introduce Arabic into biblical exegesis and had explicitly called for

231 Ibid., vol. 1, pp. 441-527.

232 Ibid., vol. 2, pp. 6-237. Also Rudbeck had written a treatise 'Om verbal se in olika språk', in UUL, MS Ihre, sig. Ihre 50. The extent to which Hallenberg was influenced by this treatise remains unclear.

233 Hallenberg, Disquisitio de nominibus in lingua Suiogothica Lucis et Visus, vol. 2, pp. 491574 .

234 A biography of Norberg is provided by C. Westerdahl, Från Norrtjärn till Konstantinopel. Matthias Norberg (1747-1826), Stockholm, 1990. On Matthias Norberg's life and writings see Gierow, Lunds Universitets historia 3, pp. 321-2; Lindroth, Svensk Lärdomshistoria, vol. 4, pp. 257-6o; on his ideas on language esp. Agrell, Studier i den äldre språkjämförelsens allmänna och svenska historia, pp. 173-200, and - very critical - Hovdhaugen and Karlsson, The History of Linguistics, p. 286.

235 For a collection of the majority of disputations see M. Norberg, Selecta opuscula academica, ed. J. Normann, 3 vols, Lund, 1817-19.

236 M. Norberg, Codex Nasaraeus: Liber Adami appellatus, Syriace transcriptus, 3 vols, Lund, 1815-16; or id., Stellae Nasaraeorum aeones ex sacro gentis codice, 2 vols, Lund, 1811.

237 M. Norberg, 'De medicina Arabum', in Selecta opuscula, vol. 3, pp. 404-20 (first Lund, 1791).

238 M. Norberg, 'De astronomia Arabum', in Selecta opuscula, vol. 3, pp. 395-403 (first Lund, 1802); and in addition id. - Anders Lizell (resp.), Dissertatio de origine astronomiae apud orientales, Lund, 1786.

239 M. Norberg, Gihan Numa: Geographia orientalis ex Turcico in Latinum versa, 2 vols, Lund, 1818, and earlier id., Specimen academicum geographiae orientalis turcico-latine, 4 vols, Lund, 1784-86; and like his predecessors id. - W. Faxe (resp.), Particula operis cosmographici Ibn El Vardi arabice et latine, Lund, 1786.

240 See e.g. M. Norberg, 'De ingenio Muhammedis', in Selecta opuscula, vol. 2, pp. 1-19 (first Lund, 1793); id., 'Quod Muhammedani de Christo sentiant', in Selecta opuscula, vol. 3, pp. 458-74 (first Lund, 1795); id., 'De templo Meccano', in Selecta opuscula, vol. 3, pp. 284302 (first Lund, 1798); id., 'Prudentia civilis ottomanica', in Selecta opuscula, vol. 2, pp. 526-82 (first Lund, 1791-92); id., 'De diaeta Turcarum, praecipue Constantinopoli', in 
this in relevant disputations. ${ }^{241}$ In his wide-ranging interest in the Oriental astral cult, in which he provided almost monographic treatments of the individual heavenly bodies, Norberg was still following the themes prescribed by Peringer. ${ }^{242}$ A special study with the title De fatis linguae Arabicae was directly modelled on the 1694 Historia. $^{243}$ In 1811, Fabian Wilhelm Ekenmann's work De lingua Sanscrit had made the discoveries of William Jones available to a wider public. ${ }^{244}$ Norberg had already matched the new interest in India, which had been an incentive for Hallenberg, with works of his own and responded with a string of disputations that tried to point out connections between the trimurti, ${ }^{245}$ Indian eschatology and various mythologemes, ${ }^{246}$ once again with

Selecta opuscula, vol. 3, pp. 310-24 (first Lund, 1808); and see id., Turkiska rikets annaler sammandragne ur dess egna urkunder, 4 vols, Kristianstad, 1822.

241 M. Norberg, 'De poëmate Jobi', in Selecta opuscula, vol. 3, pp. 17-48 (first Lund. 1786), $\S \S 6-7$, pp. 31-6; and id., Dissertatio academica de vocabulis Hebraeorum, 3 vols, Lund, 1784, passim,

242 Norberg took great interest in the celestial cult of the Sabians, see M. Norberg J. Svenander (resp.), Dissertatio de templo Solis apud Sabios, Lund, 1798; id. - A. Collin (resp.), Dissertatio de templo Lunae apud Sabios, Lund, 1799; id. - O. Sundén (resp.), Dissertatio de templo Saturni apud Sabaeos, Lund, 1799; and id., 'De religione et lingua Sabaeorum commentatio', in Commentationes Societatis Regiae Scientiarum Gottingensis, 3, 1780, pp. 1-39, and M. Norberg, 'Vierter Brief', in J.J. Björnstahl, Briefe auf seinen ausländischen Reisen, vol. 6, Leipzig, 1783, pp. 261-306. It's no miracle, that Norberg also stressed the role of a celestial cult in Zoroastrism, see id., 'De Zoroastro Bactriano', in Selecta opuscula, vol. 3, pp. 579-89 (first Lund, 1799).

243 M. Norberg, 'De fatis linguae arabicae', in Selecta opuscula, vol. 2, pp. 218-54 (first Lund, 1792), see there esp. § 3, pp. 221-24 on the pureness of Arabic, § 4, pp. 224-8, on the value of poetry, comparable to the Icelandic tradition.

244 F.W. Ekenmann - J.O. Grewillius (resp.) - C.A. Wodarg (resp.), Dissertatio academica de lingua Sanscrit, Lund, 1810, on Jones esp. Pars II, § 3, pp. 18-22.

245 M. Norberg, 'De trinitate Indiana', in Selecta opuscula, vol. 3, pp. 493-503 (first Lund, 1797). The main source for Norberg remain De Bartholomae's writings.

246 M. Norberg, 'De paradiso Indiano', in Selecta opuscula, vol. 3, pp. 504-38 (first Lund, 1797); id., 'De inferis Indianis', in Selecta opuscula, vol. 3, pp. 538-49 (first Lund, 1802); id., 'De aqua Indianis sacra', in Selecta opuscula, vol. 3, pp. 549-59 (first Lund, 1798); and id., 'De diluvio Indiano", in Selecta opuscula, vol. 3, pp. 560-7 (first Lund, 180o). The very first dissertation on Indian religion had been supervised by E. Obrecht - A. Gering (resp.), Brahmanes veteres Indorum philosophi dissertatione graduali expositi, Uppsala, 1697, see there esp. ch. 4, pp. 70-98. Obrecht of course had no access to Sanskrit at all. The first who had a scientific approach to Sanskrit literature in Sweden, comparable to today, was the ingenious Orientalist and Finno-Ugrist Abraham Herman August Kellgren, see A.H.A. Kellgren, Mythus de ovo mundano, Indorumque de eodem notio, Helsinki, 1849, esp. pp. 19-62; and id., Nala och Damayanti, en indisk dikt ur Mahabharata, Helsinki, 1852. 
the help of Neoplatonism and a patchwork drawn from Arabic and Hebrew tradition.

For Norberg as for Hallenberg, all these syncretistic schemes had to end in a grand comparison of languages, with the help of which the Lund professor, too, wanted to work through to an ultimate Semitic basis of all languages. Whereas Norberg had already attempted to derive Germanic from an archaic Persian language, ${ }^{247}$ and Greek from a variant of Hebrew, ${ }^{248}$ it was his Mithradates, first published in 1827 , that drew from this his grand conclusion. ${ }^{249}$ Norberg provided a synopsis of the 150 languages known to him, including Chinese and Tibetan, Sanskrit and Mongolian, dozens of Finno-Ugric, Samoyedic and Altaic languages, and above all a large number of native American languages, each of which he was able trace to a substrate of Hebrew and Arabic roots using the example of the Lord's Prayer. ${ }^{250}$ The project was never completed, but, as can be discovered in Norberg's unpublished letters, at the end of his life the decisive correspondences between the Semitic and native American languages led him to revive a hypothesis that was in its own way no less Swedish and baroque than his linguistic philosophy: perhaps the submerged continent Atlantis had led the first Semites, the heirs of Japheth, far beyond Sweden to the west, to America. ${ }^{251}$

247 M. Norberg, 'De origine linguae gothicae', in Selecta opuscula, vol. 2, pp. 288-304 (first Lund, 1804). On the possible skytho-slavonic origin of the biblical Chaldaeans in addition id., 'De Chaldaeis septentrionalis originis', in Selecta opuscula, vol. 3, pp. 145-73 (first Lund, 1787), here esp. $\S 6$, pp. 167-73. On the close relationship between Old Norse and Persian see already with large wordlists O. Celsius - O. Andersson (resp.), Dissertatio philologico-historica de convenientia linguae persicae cum gothica, Uppsala, 1723, passim.

248 M. Norberg, 'De origine linguae Graecae', in Selecta opuscula, vol. 2, pp. 354-65 (first Lund, 1808); and id., 'De verbis nudis et auctis Graecorum', in Selecta opuscula, vol. 2, pp. 365-72 (first Lund, 1808). The same could be said also about the letters, see M. Norberg, 'De origine literarum Graecarum', in Selecta opuscula, vol. 2, pp. 372-82 (Lund, 1804). On the close relationship to Persian see in addition M. Norberg, 'De conformatione linguae Graecae', in Selecta opuscula, vol. 2, pp. 341-64 (first Lund, 1804).

249 M. Norberg, 'Specimina orationis dominicae linguae Sinensi etc. cum dialectis Hebraea, Arabica etc. collata - Mithradates Pars I', in Nova Acta Regiae Societatis Scientiarum Upsalensis, 9, 1827, pp. 205-90, see e.g. Sanskrit pp. 227-28, Gujarati, pp. 232-3, 'Cingali' pp. 249-51, Yakut pp. 258-9, or the Komi-Zyrian language pp. 269-70.

250 On Norberg's Mithradates see Agrell, Studier i den äldre språkjämförelsens allmänna och svenska historia, pp. 179-84.

251 A collection of Norberg's letters is given by Agrell, Studier i den äldre språkjämförelsens allmänna och svenska historia, pp. 184-90. 


\section{Conclusion}

Without Hallenberg's and Norberg's opinionated syntheses, Strindberg's euphoria over the primordial language in the early twentieth century would have been unimaginable; indeed, Strindberg knew both scholars' works at first hand. It was thanks to Peringer's and Celsius's brilliance that the results achieved by Pococke or Hottinger in England and Switzerland were also appreciated in Sweden. Peringer and Celsius had ensured that Arabic studies were able to establish themselves at Swedish universities with equal right as a vehicle of scriptural exegesis, as the heir of humanity's oldest language and as an auxiliary discipline to theology. As has been made clear above, the Historia linguae et eruditionis Arabum thus held the status of a model to be emulated, and its influence can be traced in successive works across almost a century. Comparing Europe as a whole, these initial reasons for Arabic studies with their strategies of justification in Sweden probably did not differ much from the developments in the subject in the other countries of central Europe.

Yet Peringer and Celsius had also been ready, if with some reservations, to subordinate the study of Arabic to a further goal, namely verification of the theses maintained by Rudbeck and his followers in Sweden. Arabic studies in this way had to become a piece of a theoretical mosaic in which the glory of Sweden was the ultimate goal of argument and which aimed to understand Arabia from the perspective of the North. Hallenberg's and Norberg's ambitious schemes show that, despite the autonomy of the discipline and its subjects of study, this national motive was still influencing Arabic studies in Sweden into the early nineteenth century. This distinctive path, too, with premises that could hardly have been shared by anyone beyond Sweden, had already been mapped out at the end of the seventeenth century. 